\title{
Unpacking the Effect of Decentralized Governance on Routine Violence: Lessons from Indonesia
}

September 9, 2016

\begin{abstract}
We study the effect of decentralization on routine violence in Indonesia. We unpack decentralization along multiple dimensions and consider the individual effects of local elections, the creation of new administrative units, fiscal transfers, and local public service delivery. We use comprehensive data from Indonesia's National Violence Monitoring System (NVMS), a new dataset that records the incidence and impact of violence in Indonesia. We use these data to examine the relationship between the different dimensions of decentralization and different types of local violence in Indonesian districts between 2001 and 2010. Our analyses suggest that there is a positive association between local service delivery and at least some forms of violence. We argue that the positive effect of service delivery on violence is due to newly generated distributive conflicts among local ethnic groups around the control over and access to services. By comparison, district splitting and the introduction of direct elections of district heads are negatively associated with some forms of violence. There is little evidence that fiscal transfers, in general, mitigate conflict.
\end{abstract}

Word Count (without references): 10,163 


\section{Introduction}

What is the effect of decentralized governance on local, routine violence? ${ }^{1}$ A large literature in political science and economics has hypothesized links between formal decentralization reforms and, amongst other outcomes, political violence and conflict (see Treisman 2007 and Wibbels 2006 for reviews). On the one hand, scholars have hypothesized that decentralization can reduce the risk of political violence, in particular separatism and ethnic conflict, by increasing local autonomy over allocative decisions, protecting minority rights, improving social service provision, or funneling fiscal resources to peripheral regions to assuage grievances (e.g., Brass 1991, Hechter 2000, Horowitz 1991, Gurr 2000). On the other hand, some scholars argue that decentralization can amplify the risk of conflict by strengthening ethnic identities (Kymlicka 1998, Hechter 2000), enabling discrimination against local minority groups (Horowitz 1991, Lijphart, Rogowski and Weaver 1993, Duncan 2007), or by providing local groups the necessary political and material wherewithal to challenge the central government (e.g., Bunce 1999, Snyder 2000). Cross-country tests of the effects of decentralization on conflict and violence have yielded conflicting evidence. While some find conflict-reducing effects of decentralization or federalism (Saideman et al. 2002), others find no clear effects (Selway and Templeman 2012) or evidence of conditional relationships (Brancati 2006, Wibbels and Bakke 2006, Schneider and Wiesehomeier 2008).

We add to the existing literature by offering two innovations. First, we consider the effects of decentralized governance on more local, small-scale forms of violence. Second, we disaggregate decentralization into various dimensions. With respect to the first point, many studies of decentralization and violence narrowly focus on large-scale separatism or inter-communal violence (e.g., Brancati 2006, Schneider and Wiesehomeier 2008). ${ }^{2}$ We consider the consequences of decentralized governance for different forms of small-scale violence in Indonesia. In Indonesia's recent history, political and social violence has played an important role at the national and local level (Aspinall

\footnotetext{
${ }^{1}$ We distinguish between violence, "the physical or real forms of acts, such as destructions, killings, looting, attacks, burning, clashes, taking hostages, ..." and conflict, which refers to underlying processes that produce acts of violence (p.4, Tadjoeddin 2002). See also Brubaker and Laitin (1998).

${ }^{2}$ Some studies consider more small-scale events, like ethnic protests or riots (Saideman et al. 2002, Wibbels and Bakke 2006, Selway and Templeman 2012), but nonetheless tie these analyses to broader mobilization attempts within the framework of ethnic conflict.
} 
2009, Bertrand 2004, Sidel 2006, Purdey 2006, Panggabean and Smith 2011). Although much attention has been paid to high-profile large-scale violence, such as separatism and high-intensity ethno-communal conflict (see Section 2), it has declined dramatically since 2003, while everyday or routine forms of violence remain prevalent in Indonesia (Barron, Jaffrey and Varshney 2014). Analyzing decentralization's effect on routine violence presents two opportunities. First, it broadens the analytical focus of the decentralization and violence debate, testing the extent to which arguments often developed with respect to separatist violence or large-scale ethnic conflict apply to other types of violence. Likely, decentralized governance structures play an important role in mediating and structuring the production of routine violence at the local level. Second, the massive human cost associated with Indonesia's ebb and flow in local violence between 2001 and 2010 generates the need for a better understanding of its relationship with Indonesia's 'big-bang' decentralization program (World Bank 2001).

With respect to the second innovation, we believe that the mixed findings in the large $\mathrm{N}$ crosscountry literature are in part due to a lack of sufficient disaggregation in the measurement of decentralization. Existing work often treats decentralization as a compound treatment, failing to distinguish between the specific elements of large scale decentralization reforms and ensuing changes in governance. Specifically, it is instructive to distinguish the effects of decentralized accountability mechanisms (i.e., local elections ${ }^{3}$ ), the decentralized responsibility for and delivery of public services by local governments, and the allocation of fiscal resources to the local level. Changes in the territorial structure of government, the re-drawing of administrative boundaries, which often ensues in the wake of decentralization, is also important (Grossman and Lewis 2014). While many quantitative cross-country studies often lump these dimensions into one compound treatment of decentralization, others focus too narrowly on a single dimension, failing to consider that the effects of decentralized governance might operate through different channels. ${ }^{4}$ Disentangling the interplay of the different dimensions of decentralized governance and routine violence in Indonesia presents

\footnotetext{
${ }^{3}$ Direct elections to district head office were introduced in Indonesia in 2005.

${ }^{4}$ E.g., Brancati (2006) uses either a binary indicator for the presence of a regional legislature with independent decision-making power in one issue area or a four-point index that combine elements of local elections with the extent of decision-making authority across issue areas. Wibbels and Bakke (2006) focus on fiscal decentralization variables, while Schneider and Wiesehomeier (2008), Saideman et al. (2002) or Selway and Templeman (2012) simply employ dummy variables for the presence of federalism.
} 
a unique opportunity to add empirical insights to ongoing research and policy debates.

Focusing on Indonesia has a number of important advantages. For one, we are able to identify useful measures of Indonesia's decentralized governance along multiple dimensions, ranging from direct head elections, center-local fiscal transfers, public service delivery, to district splitting. Moreover, only studying within-country variation in violence allows us to hold constant a number of unmeasurable confounders that make cross-country comparisons problematic. With respect to measuring routine violence, Indonesia's National Violence Monitoring System (NVMS) records the incidence and impact of violence in Indonesia over a 15-year period beginning in 1998 at a sub-national level. These unique data allow us to examine the relationship between decentralized governance and different types of local violence. While an interesting and important case in it of itself, this case study of Indonesian districts should also be of interest to a broader audience and inform more general debates about the relationship between decentralized governance and violence in other multi-ethnic, post-authoritarian developing countries.

Our quantitative analysis relates the number of violent events in each district-year between 2001 and 2010 to our main measures of decentralized governance. ${ }^{5}$ Relying on observational data, standard concerns about causal identification exist. We implement a number of strategies to limit and mitigate problems of endogeneity - ranging from the inclusion of a large set of control variables, to models that account for unobserved, time-invariant heterogeneity, to instrumental variable estimations - to increase the confidence in our results. Our analysis reveals a number of noteworthy findings. Our results indicate a positive effect of decentralized service delivery on violence. We further substantiate this effect in a series of statistical tests ruling out reporting bias, reverse causality and other, alternative explanations. We also supply evidence that this positive association between service delivery and violence is reversed at very high levels of service delivery. We attribute this finding, in part, to grievances generated when groups are excluded from service delivery and to inequitable access to service delivery in localities with horizontal competition between ethnic groups. This finding is consistent with and expands prior work on horizontal inequalities and conflict from the Indonesian context (Diprose 2009; 2008a).

\footnotetext{
${ }^{5}$ We use 2001 as the start year of our analysis, because this is when the first elements of Indonesia's decentralization reform took effect. We use 2010 as our end year due to data constraints. Some of our control variables are only systematically available until 2010 .
} 
By comparison, other dimensions of the decentralization reform program have had largely pacifying effects on violence. District splitting is negatively associated with most forms of violence. Newly created districts are much less likely to experience a large number of resource, identity, and popular justice related violent events, as well as crime. The introduction of direct elections at the district level, the timing of which was exogenously determined thus allowing for causal inference, is also negatively associated with the total number of violent events and crime. Yet, the introduction of direct head elections is positively associated with electoral violence, likely due to the violent contestation of results in some contexts. This finding suggests that improved accountability at the local level might mitigate some types of violence but also increase other types of violence, such as electoral violence. The effects of fiscal transfers on violence are largely non-significant for the whole sample.

This paper makes useful contributions to several ongoing scholarly debates. First, we add to the growing discourse on decentralization and violence by distinguishing different elements of decentralized governance and analyzing small-scale, local violence. Second, our finding on the positive association between service delivery and violence suggests that concerns of equitable access have to be taken seriously by governments and donors when designing and implementing service delivery projects. Third, our study also adds to the debate on the determinants of violence in Indonesia. Prior empirical analyses of violence in Indonesia have studied related issues, but largely relied on qualitative accounts of specific events or regions (e.g., van Klinken (2007), Bertrand (2004), Wilson (2008), Sidel (2006), Davidson (2008), McRae (2013)) or on fairly aggregated units of analysis (Varshney, Tadjoeddin and Panggabean 2008). Other analyses have not focused on the specific role of decentralization reforms (Barron, Kaiser and Pradhan 2009, Tajima 2013). Our paper extends prior work on small-scale violence (Tadjoeddin and Murshed 2007, Østby et al. 2011) and decentralization (Diprose 2009, Murshed, Tadjoeddin and Chowdhury 2009) by allowing for a broader analysis of the relationship between decentralized governance and local violence in Indonesia, while unpacking the effect of decentralization along multiple dimensions. 


\section{The Indonesian Context}

Taking effect in 2001, Indonesia's 'big bang' decentralization is one of the most ambitious decentralization reforms to date and has dramatically re-shaped the allocation of authority across levels of government (World Bank 2001, Hofman and Kaiser 2004, Turner et al. 2003). Reforms were passed in 1999 in an environment of political upheaval and uncertainty in the wake of the fall of the Suharto regime (Crouch 2010). ${ }^{6}$ Triggered by a massive financial crisis, Indonesian elites had to manage an unexpected political transition while trying to resolve an economic crisis. Relying on the advice from a technical expert panel, with support and influence by international donors like the World Bank, the government and parliament opted for wide-ranging decentralization reforms in expectation of reaping electoral rewards in a newly competitive, democratic environment (Smith 2008, Turner et al. 2003). The unexpected extent of the decentralization reforms radically empowered district governments, as opposed to the central or provincial levels of government.

As a consequence of the reforms, a new system of decentralized governance was created with wide-ranging consequences for local accountability, the allocation of fiscal resources across levels of government, and service delivery. Four aspects of this decentralized governance system are of particular importance. First, district governments were assigned the responsibility to provide the majority of public services, including health care, education, and infrastructure. ${ }^{7}$ Second, the increase in districts' responsibilities for providing public goods and services was complemented by fiscal reforms. A system of intergovernmental transfers was established to provide districts with the necessary fiscal resources. Local governments are heavily reliant on the center for fiscal resources as they lack significant own-source revenues due to low local taxation efforts (Lewis 2014). ${ }^{8}$ Between 2001 and 2010, the period of our analysis, the amount of fiscal transfers to local governments approximately doubled (Lewis 2014). Third, the introduction of free and fair elections for local

\footnotetext{
${ }^{6}$ Portions of the decentralization law were revised in 2004.

${ }^{7}$ Approximately 60 percent of local government spending on average is allocated to service delivery in these three sectors (Lewis 2013).

${ }^{8}$ In fact, the national property tax has only recently been decentralized (Lewis 2014). The lack of own-source revenue has its root in the heavily centralized system of tax revenue allocation established during the New Order. Although the decentralization reforms transferred substantial policy authority to the districts, they did not empower them fiscally to the same extent.
} 
executive and legislative office offered ordinary Indonesians the opportunity to hold local leaders accountable. Starting in 1999, Indonesian voters elected representatives to national, provincial, and district legislatures. Starting in 2001, the decentralization reforms gave local legislatures, together with the district head, control over local expenditures. From 1999 to 2004 district heads were selected by a majority within the local parliament. Direct elections for the district head office were introduced in 2005. This change in selection procedures was motivated by widespread corruption at the local level, where powerful party operatives would sell votes in the local legislature to rich candidates for the district head office (Buehler and Tan 2007). This institutional change has created a vibrant, albeit still elite-dominated, local electoral process (Erb and Sulistiyanto 2009). Fourth, in addition to decentralizing essential government functions to the district level, Indonesia also significantly and somewhat unintentionally increased the number of local governments, from 292 in 1999 to 497 in 2012. A provision of the decentralization reforms changed the rules for jurisdictional boundary changes and, given the increased power of local government, dramatically altered the value and ease of creating new districts. Local elites, often drawing on the desire of local ethnic groups for better representation, lobbied the central government and legislature to split existing districts, as well as provinces (Cohen 2003, Ford 2003, Fitrani, Hofman and Kaiser 2005, Nordholt and van Klinken 2007, Kimura 2013, Pierskalla 2016). The proliferation of territorial administrative units is not a necessary feature of decentralization reforms as it also occurs in centralized regimes. Yet, it often takes place in the wake of decentralization reforms or democratic transitions, due to the changed value of local government (Grossman and Lewis 2014).

In parallel to these dramatic political changes, Indonesia's recent history also featured widespread social and political violence: early incidents of communal violence in the 1990s (Varshney, Tadjoeddin and Panggabean 2008); Anti-Chinese riots following the Asian financial crisis and contributing to the downfall of the Suharto regime (Purdey 2006, Panggabean and Smith 2011); large-scale inter-ethnic and inter-religious violence in the early 2000s (Sidel 2006, Barron, Kaiser and Pradhan 2009, van Klinken 2007, McRae 2013), separatist conflicts between the central government and rebel groups in Aceh, Papua, and East Timor (Aspinall 2009, Bertrand 2004, Tadjoeddin 2011); and terrorist acts by fundamentalist Islamic groups (Abuza 2007, Sidel 2006). Since the early 2000s large-scale violence has abated, but every-day forms of violence (e.g., group brawls, violence in the 
pursuit of popular justice, or violent crime) have remained common, especially in provinces with a history of violence (Barron, Jaffrey and Varshney 2014).

A substantial research literature has emerged that deals with explanations of these different types of violence in Indonesia. For example, Tadjoeddin (2011) identifies economic grievances over the exploitation of natural resources as a main motivation for separatist violence. In contrast, other prominent analyses highlight the role of agency and context in motivating Acehenese separatism, emphasizing that economic grievances alone are insufficient to understanding the conflict (Aspinall $2007 ; 2009)$.

Large-scale communal violence in the early 2000s, in the context of mobilized inter-group rivalry and conflict, has received particular attention in the literature. Prominently, Bertrand (2004) attributes the various forms of violence that erupted in the aftermath of President Suharto's fall in 1998 to the re-negotiation of Indonesia's "National Model" - a reflection of changes in the role of Islam in politics, the balance of power between various identity groups, and the relationship between the central and regional governments. This change intensified separatist conflicts in the provinces of Aceh and Papua but also communal violence between ethno-religious communities in Maluku and Kalimantan. Others identify intra-elite competition (van Klinken 2001), the increasing role of access to local state resources (van Klinken 2007), the lack of religious institutionalization (Juan, Pierskalla and Vüllers 2015), or poverty, inequality and shocks to economic development (Barron, Kaiser and Pradhan 2009, Tadjoeddin, Suharyo and Mishra 2001) as drivers of communal violence. Horizontal inequality has also been identified as one potential source of communal violence in Indonesia (Mancini 2008, Barron, Kaiser and Pradhan 2009). In contrast, Tajima (2013) develops an argument about mismatches between formal and informal security institutions at the local level.

Both separatist and the large-scale inter-communal violence of the late 1990s and early 2000s are distinct from small-scale violence. Endemic, low intensity violence ranges from violence related to poplar justice, group brawls, to election, governance and resource extraction related violence, but falls short of highly organized forms of conflict between regional groups and the state (i.e., separatism) or episodic incidents of large-scale ethno-communal violence (Tadjoeddin and Murshed 2007). This type of violence differs from separatism and large-scale inter-communal violence in the level of intensity, its geographic concentration, and the degree to which mobilization frames 
and organization play an important role (Tadjoeddin and Murshed 2007). More local forms of everyday and routine violence are equally important to consider, but have received comparatively less attention in the literature (Barron, Jaffrey and Varshney 2014). Notable exceptions with respect to small-scale violence in Indonesia are work by Tadjoeddin and Murshed (2007), who investigate the interplay between socioeconomic factors, like growth, poverty and human development, with routine violence in Java or Østby et al. (2011), who also consider routine violence and document an effect of population pressures.

On the specific link between Indonesia's decentralization reforms and violence, a number of qualitative and quantitative studies have generated important hypotheses and findings. For one, the decline of separatist violence in Indonesia has been attributed to special autonomy provisions for Aceh and Papua. These special provisions, paired with the general decentralization reforms, enabled leaders of separatist movements to gain electoral office and dampened overall separatist sentiments (Mietzner 2007, Tadjoeddin 2011). Focusing on communal and local forms of violence, Diprose (2009) finds that local authority over services and local elections have mitigated some grievances, but also generated new tensions over the creation of new districts and the outcome of elections. In a case study of two districts in Central Sulawesi, Diprose (2008b) elucidates the various mechanisms through which decentralization has reduced, but also generated new forms of violence. For example, the introduction of local elections has addressed grievances about local representation, but also engendered intensified competition over local office. The creation of new districts has equally ameliorated some ethnic conflict by increasing ethnic homogeneity within newly drawn districts, but also created new venues for violent conflict over the control of local government. Diprose and Ukiwo (2008) argue that the conflict mitigating or conflict increasing effects of decentralization depend on the level of horizontal inequalities between identity groups. In a chapter on electoral violence, Tadjoeddin (2014) finds that electoral violence is higher in rural, less developed districts. Last, another set of studies analyzes the effects of fiscal transfers on violence. Murshed, Tadjoeddin and Chowdhury (2009) find that fiscal transfers reduce routine violence in a set of Javanese districts, while Tadjoeddin (2014) argues that center-local fiscal transfers have also contributed to increased inter-ethnic cooperation in order to facilitate the appropriation of fiscal resources. 
Our study builds on and extends this prior work in the following ways. First, our focus on local, small-scale forms of violence adds to the smaller body of work that engages the issue of routine violence. This is important because large-scale inter-communal violence and separatist violence have abated dramatically since the early 2000s. Everyday, small-scale violence has continued to be relevant across Indonesia and throughout the period in which decentralization reforms re-shaped local governance structures. Second, the existing cross-national literature on the effects of decentralization and violence has largely focused on separatism or large-scale ethnic violence (e.g., Brancati 2006, Wibbels and Bakke 2006, Selway and Templeman 2012), often ignoring routine violence. Third, we build on Indonesia-specific work on violence and decentralization by providing a broader empirical perspective, covering a much larger set of districts and time frame than other studies (e.g., Diprose $2008 b$ considers two districts in Central Sulawesi, while Murshed, Tadjoeddin and Chowdhury 2009 focus on districts in Java). As such, this allows us to test specific hypotheses about the effect of decentralization with a broader set of cases and provide more systematic evidence. Moreover, while other studies often focus on one specific aspect of decentralization (e.g., Diprose 2009 considers local elections and district splitting, while Murshed, Tadjoeddin and Chowdhury 2009 focus on fiscal transfers), we evaluate the partial effects of specific dimensions of decentralization, holding other aspects of decentralized governance constant.

\section{Decentralized Governance and Local Violence}

In developing and ethnically diverse polities decentralization reforms are often implemented as a tool for improving local service provision, mitigating social tensions, and enhancing the prospects for political stability (Bardhan 2002). Decentralization reforms aim to strengthen the decisionmaking power of local governments and empower the citizens of local communities with a greater policy-making and oversight role. Systems of inter-governmental fiscal transfers in turn provide the necessary resources to enable less well endowed regions to exercise their newly allocated authority over service provision. Decentralization reforms are also increasingly coupled with a proliferation of local government units (Grossman and Lewis 2014), because the vertical allocation of fiscal and political authority increases the value of local government units to local populations. Such reforms create new systems of decentralized governance, where local bureaucracies provide essential gov- 
ernment services, citizens can hold local leaders accountable and lobby for changes in jurisdictional boundaries, and local leaders have discretion over the use of central government transfers.

What are the effects of decentralized governance on local forms of small-scale violence? We draw on existing arguments from the decentralization literature and specific work on Indonesia to develop a number of specific hypotheses about the effects of decentralized governance on routine violence. We distinguish different aspects of decentralized governance when considering its impact on local forms of violence. Specifically, we distinguish between the effects of local electoral accountability, changes to local government boundaries, the size of fiscal transfers, and the local provision of government services.

\subsection{Local Elections}

Classic approaches to decentralization and federalism usually expect a substantial peace dividend. By allocating powers over politics and the economy to local groups, decentralization is expected to reduce ethnic conflict and secessionism (e.g., Brancati (2006), Hechter (2000), Lijphart (1977), Lustik, Miodownik and Eidelson (2004), Horowitz (1991), Gurr (2000)). Further, federal institutions can provide a check on the central government to ensure that it is not dominated by majority ethnic groups, thus reducing minority groups' fears and the ethnic security dilemma (Posen 1993). These arguments aim at understanding center-periphery conflicts from a country-level perspective and are not directly applicable to understanding sub-national variation in local, small-scale violence. Increasing local accountability through the introduction of local direct elections has implications for small-scale violence. Routine, everyday forms of violence are still tied to local grievances and socio-economic changes (Tadjoeddin and Murshed 2007). The failures of government to address or ameliorate grievances and socio-economic hardships could be tied to a lack of accountability of local politicians and bureaucrats to the local population. Moreover, failures of local governments to effectively provide security and regulate local conflicts can contribute to endemic vigilantism. If decentralization implies the transfer of political authority to the local level, paired with a strengthening of local accountability relationships with elections, then local minority groups will gain opportunities to regulate their own affairs. This increase in accountability, representation, and legal avenues for conflict resolution ought to mitigate conflicts among local identity groups and allow 
local government to address grievances more effectively, which has been raised as a possibility in the Indonesian context (Diprose 2009). Hence, local elections ought to reduce violence:

Hypothesis 1a: Local elections reduce violence.

This effect should be particularly relevant for forms of violence that are related to governance, popular justice, and identity issues, since these are tied most directly to local elections. Yet, under certain conditions the decentralization of political institutions may intensify ethnic and communal conflict and produce more violence. Local elections can intensify conflict by: supplying local groups with the resources they need to further discriminate against rival groups, such as control over the local police and media (Bunce 1999, Snyder 2000, Roeder 1991); reinforcing local identities (Hechter 2000); or enabling local governments to exploit their newly gained authority against particular minority groups (Duncan 2007). Elections can also produce violence by creating opportunities for local groups ato compete for the control of the local government apparatus (Diprose 2009):

Hypothesis 1b: Local elections increase violence.

This potentially pernicious effect of local elections should be most relevant for violence related to the election itself.

\subsection{The Proliferation of Local Government Units}

Distinct from re-allocating political authority to the local level, decentralization reforms sometimes include dramatic changes to the number and size of sub-national territorial units (Fitrani, Hofman and Kaiser 2005, Kimura 2013). This re-organization of territorial structures provides opportunities to create new local governments that more closely match local identity groups and allows them to exercise authority over their communities. The multiplication of opportunities to exercise such authority through the creation of new sub-national units may induce a reduction in local violence. Qualitative work on district proliferation in Indonesia has found some examples in which the creation of new districts seems to have mitigated some grievances, especially around issues of group identities (Mietzner 2014, Diprose 2008b):

Hypothesis 2a: District creation reduces violence.

Again, this effect of unit proliferation should be most relevant for identity related violence, since 
the process of unit proliferation is closely affected by the desire of local groups to attain their own local government structures (Grossman and Lewis 2014, Pierskalla 2016). On the other hand, the creation of new sub-national units might heighten tensions between local identity groups, if the process favors particular groups, or violence can be used as a strategy to prompt the creation of new local governments (Nolan, Jones and Solahudin 2014). The proliferation of local government units might also increase the probability of violence because it creates new venues for competition over resources (Diprose 2008b). Hence, one might formulate a competing hypothesis that predicts a positive association between institutional decentralization and conflict:

Hypothesis 2b: District creation increases violence.

\subsection{Fiscal Transfers}

Systems of fiscal transfers are generally seen as a potential mitigating factor for ethnic violence. For example, the survival of Russia after the fall of communism can be attributed in part to the federal arrangements and the national government's capacity to purchase the acquiescence of separatist regions with fiscal transfers (Treisman 1999). Similar arguments have been made about the use of fiscal transfers and special autonomy allocations in the Indonesian case (van Klinken 2007, p.45). While these conventional arguments aim to understand the conflictual relationship between regional identity groups and the central government, similar implications might follow for

low intensity communal violence. Larger transfers of fiscal resources to local government might mitigate a number of local conflicts by increasing the pool of available resources that can be leveraged to pacify contentious groups (Murshed, Tadjoeddin and Chowdhury 2009). Localities enjoying substantial fiscal transfers might simply experience fewer local conflicts, not because of improved conflict resolution or better representation, but simply because acquiescence can be more easily bought. Hence, we might expect that higher levels of fiscal transfers are associated with lower levels of violence:

\section{Hypothesis 3a: Fiscal decentralization reduces violence.}

Again, some scholars have instead argued that fiscal decentralization can exacerbate ethnic tensions (Suberu 2001) and is likely to contribute to conflict in contexts where high levels of inequality overlap and exaggerate ethnic differences (Wibbels 2006) or where there are large encompassing 
national governing parties that exclude minority regions (Wibbels and Bakke 2006). More gener-

ally, a large literature on conflict has identified a link between the size of rents available for capture and violence (Grossman 1991, Le Billon 2012, Lujala 2009). Parallels exist for the occurrence of local, small-scale violence. Large fiscal transfers increase the value of controlling local government and intensify competition over access, which might translate into more local violence:

\section{Hypothesis 3b: Fiscal decentralization increases violence.}

\subsection{Local Service Delivery}

Going beyond the purely fiscal dimension, we also consider citizens' access to local service delivery and its effects on conflict. The vast literature on decentralized service delivery tends to focus on elite capture and the role it plays in obfuscating accountability (Bardhan 2002). Instead, we turn to the broader literature on civil wars, development aid and social movements to identify the channels through which public services can mitigate or contribute to the risk of conflict. Somewhat surprisingly, the literature is divided over whether levels of service delivery reduce conflict and violence. We identify at least four distinct theoretical mechanisms that link the level of service provision to violence. The first two mechanisms suggest that public service delivery mitigates violence and the latter two point to the opposite direction.

The first channel emphasizes the role that improvements in service delivery can play in eliciting popular support from citizens and reducing violent conflict (Berman, Shapiro and Felter 2011, Horowitz 1985, Beath, Christia and Enikolopov 2012). States that are unable to provide public goods can elicit violent clashes between organized groups or violence against the state, because citizens are likely to withdraw their legitimacy from the state (Bates 2008). Hence, improved local service provision should engender popular support and can address a variety of grievances that might otherwise contribute to inciting violence.

The second mechanism focuses on the function of service delivery in improving labor market opportunities and increasing the opportunity costs of joining insurgencies thereby mitigating violence - with albeit mixed evidence (Berman, Shapiro and Felter 2011, Crost, Felter and Johnston 2014, Fearon, Humphreys and Weinstein 2009). These two mechanisms imply that improved decentralized service delivery should lower various forms of violence. Improved service delivery mitigates 
grievances and improves local labor market conditions, which, in turn, should reduce violence:

Hypothesis 4a: Improved decentralized service delivery reduces violence.

The third and fourth mechanisms suggest a positive association between decentralized service delivery and violence. The third mechanism identifies the role that infrastructure, including roads and communication technologies, can play in facilitating violent collective action. Research on social movements and civil wars suggests that the availability of infrastructure can help citizens to overcome collective action and coordination problems, producing overall higher levels of contentious collective action (McAdam, Tarrow and Tilly 2001). Improved communication through cell phones and other means can facilitate organization and real time coordination of groups for the purpose of violent collective action (Pierskalla and Hollenbach 2013). Road networks facilitate the flow of supplies and fighters into and out of target areas, increase access to otherwise isolated areas, and facilitate the transmission of violence between locations (O'Loughlin, Holland and Witmer 2011, Zhukov 2012). These effects are likely to be relevant for small scale violence too, hence, improved local provision of infrastructure can inadvertently empower citizens and facilitate violent collective action.

The fourth mechanism emphasizes the consequences of distributive conflicts that are often inherent to public service delivery. When resources are distributed according to identity based on ethnicity, religion, home region, or political party affiliation, they can yield horizontal inequalities, and consequently, contribute to conflict. Cederman, Weidmann and Gleditsch (2011) argue that horizontal inequalities between politically relevant ethnic groups can contribute to ethnonationalist conflict and provide support for this argument through quantitative analyses. A large literature on the relationship between inequality and conflict also posits that especially in contexts where rapid development triggers rising expectations (Gurr 1970, Davies 1962), inequalities in income, access to goods and services and politics can create discontent and a sense of injustice that may yield grievances which contribute to the emergence of conflict (Cederman, Weidmann and Gleditsch 2011, Muller and Seligson 1987, Brown 2008). When the opportunities arise and groups are able to organize and mobilize, those excluded from the resources may fight to get a more equitable share (Cederman, Weidmann and Gleditsch 2011, 8-9). Similar points have been made about the role of horizontal inequalities for ethnic and local violence in Indonesia (Mancini 2008, Tadjoeddin 2014, 
Diprose and Ukiwo 2008).

This implies that areas with poor service delivery might experience comparatively less violence because access is equally poor for all groups. Improving the delivery of public goods and services via decentralization can aggravate grievances of excluded minorities if heightened expectations are met with inequitable access. These mechanisms suggest a competing hypothesis:

\section{Hypothesis 4b: Improved decentralized service delivery increases violence.}

\section{Data}

\subsection{Description of NVMS}

To study the effects of decentralized governance on routine violence fairly disaggregated data is needed. Globally, high quality data on violence is rare. In the Indonesian context researchers have relied on provincial-level data collection efforts (Varshney, Tadjoeddin and Panggabean 2008) or specific questionnaire items from the Indonesian Village Census (PODES) to track especially high intensity forms of ethno-communal violence. Recent efforts by the Coordinating Ministry for People's Welfare, with support from the Habibie Center and the World Bank, have led to the creation of the The National Violence Monitoring System Indonesia (NVMS). The NVMS collects information on violent events across a selection of Indonesia's 34 provinces. ${ }^{9}$ From 1997 to 2013, year coverage varied among the following provinces: Aceh, Maluku, North Maluku, Papua, West Papua, West Kalimantan, Nusa Tenggara Timur, Central Sulawesi, West Java (partial), Banten (partial), Central Kalimantan, East Kalimantan, Lampung and Nusa Tenggara Barat. ${ }^{10}$ From 2013, the dataset has national coverage. Information is largely drawn from local newspaper sources, but supplemented by NGO reports or other reputable sources. Raw news reports are digitally archived and processed to select information on specific events that involved the use of violence. The basic entry in the data refers to a distinct violent event. The project considers incidents to be violent if:

\footnotetext{
${ }^{9}$ The appendix provides detailed information on the geographic and temporal coverage of the database. Note that the number of provinces was increased to 34 in the time period covered by the database.

${ }^{10}$ Initial provinces were selected based on the presence of conflict. This means our inferences apply largely to the set of cases for which there some minimum threshold of violence is achieved. This might generate selection bias for some of our findings, which we discuss in more detail below.
} 
actions cause or may cause physical harm to humans or property; actions restrict physical freedom of individuals or groups; and actions are intentional. ${ }^{11}$

The NVMS tracks a number of different categories of violent events for this time period. The coding scheme distinguishes among separatist, resource, governance, election, identity, popular justice, law enforcement, crime, and domestic violence. ${ }^{12}$ Since the purpose of our study is to analyze the effects of decentralization on local forms of violence, we exclude separatist violent events and domestic violence from our analysis. The remaining types of violence cover a broad range of violent events that fall in the general category of routine violence. Resource-related violence involves resource disputes including around land, mining, access to employment, salary and pollution. Governance-related violence involves responses to government policies or programs (including public services, procurement/corruption, subsidy, region splitting, and security forces). Election and appointment-related violence is a response to electoral competition and bureaucratic appointments. For shorthand, we refer to election and bureaucratic appointment-related violence in the subsequent discussion and in the tables as electoral violence. Identity-related violence involves group identities (e.g., religion, ethnicity and tribe). Violence coded as popular justice involves acts perpetrated by groups to respond to and punish an actual or perceived wrong. Violence involved in law enforcement involves violent action taken by members of formal security forces to perform law-enforcement functions. Crime refers to violence not triggered by a prior dispute or directed towards specific targets. We include violent events related to crime in our analysis, since it is related to the quality of local governance. The category of identity-related violence also includes violence during the period of large-scale ethno-communal conflict from 1998 to 2002. Since our study focuses on the time-period of decentralized governance from 2001 onwards, the data mostly speak to low-intensity violence.

This effort is a substantial improvement over prior data collection exercises (e.g. Varshney, Tadjoeddin and Panggabean 2008) or official data from the Indonesian government (e.g., information on communal violence from PODES) in terms of geographic disaggregation, temporal coverage,

\footnotetext{
${ }^{11}$ In our robustness checks we also consider an analysis that only includes events with fatalities.

${ }^{12}$ While that the data distinguish between a number of important forms of violence, they do not let us speak to all relevant types of violence in Indonesia. For example, our data says little about terrorist violence, because it is not distinguished specifically in the coding of violent events.
} 


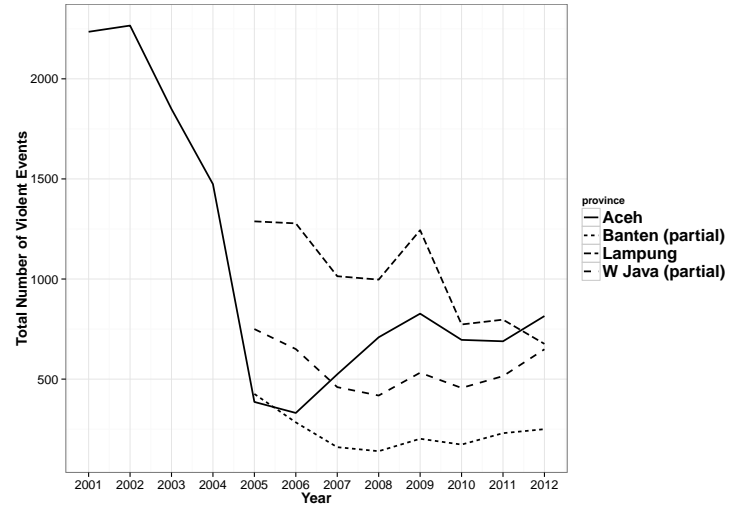

(a)

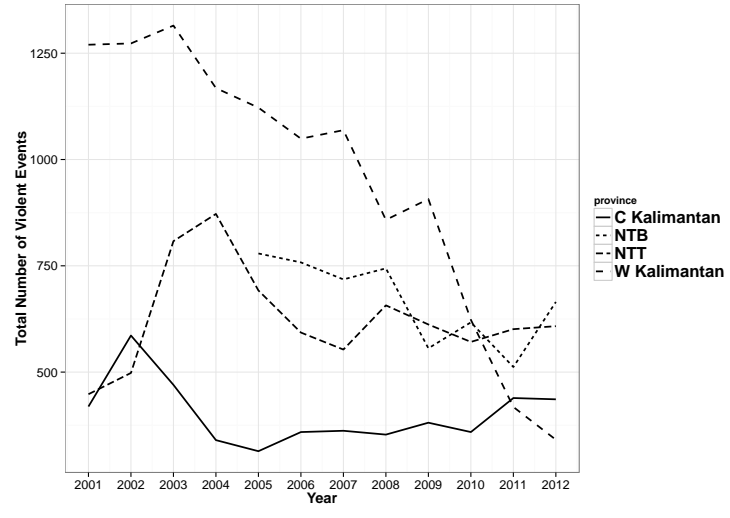

(b)

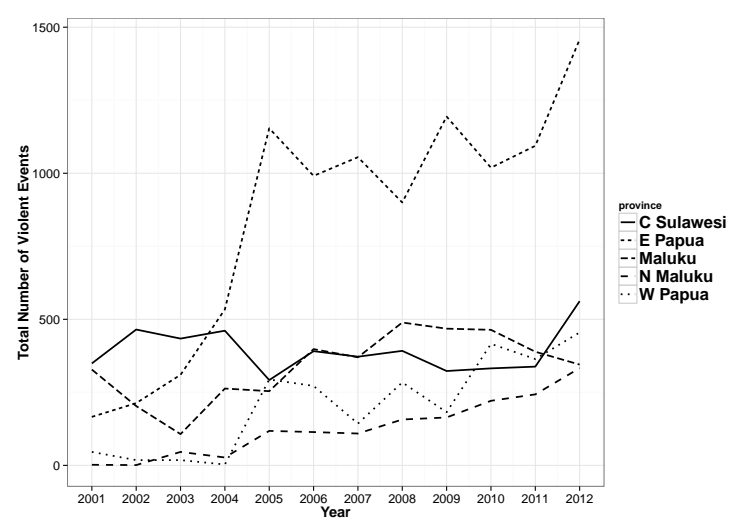

(c)

Figure 1: Number of Violent Events by Province.

types of violence and underlying source material. An early pilot-study related to the NVMS found substantially more violent events as a result of utilizing local newspaper sources, as compared to existing datasets (Barron and Sharpe 2008).

Figure 1 plots the total number of events (across the seven categories we consider) for each of the provinces in the database. 


\section{Mean No. of Violent Events 2001-2012 (SPNK)}

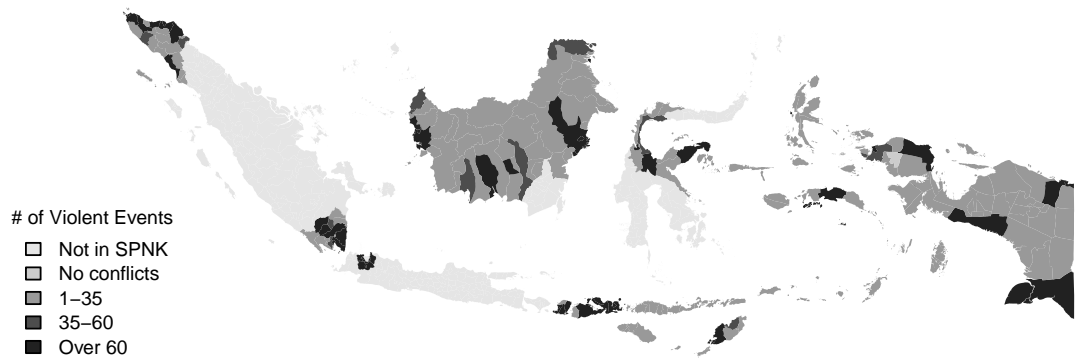

Figure 2: Mean Number of Violent Events 2001-2012 by District

Figure 1 illustrates the dramatic variation in violence across provinces and over time. The NVMS data document, for example, a precipitous decline in violence in Aceh and West Kalimantan, whereas East Papua has experienced a marked increase in violent events over the same time period. Figure 2 visualizes the geographic variation in violence using a map with the mean number of violent events from 2001 to 2012 by district. 


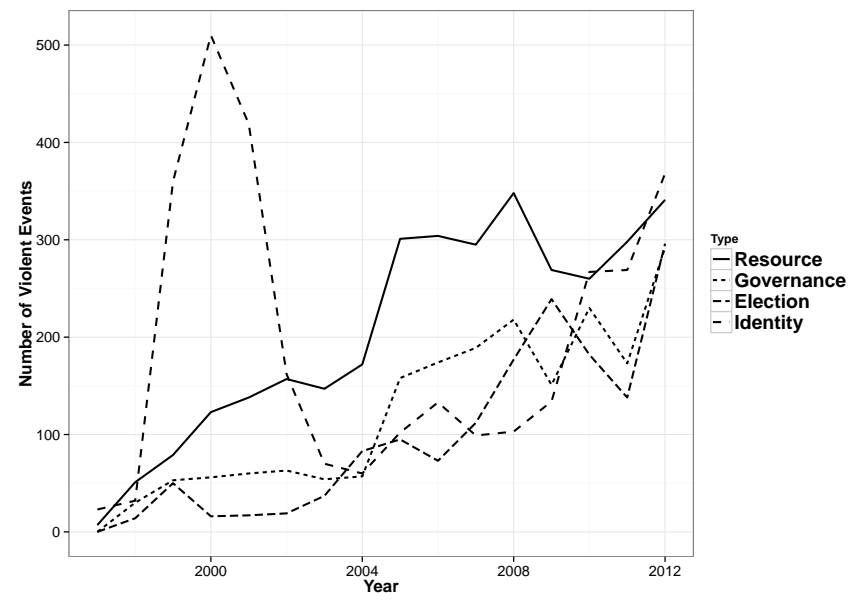

(a)

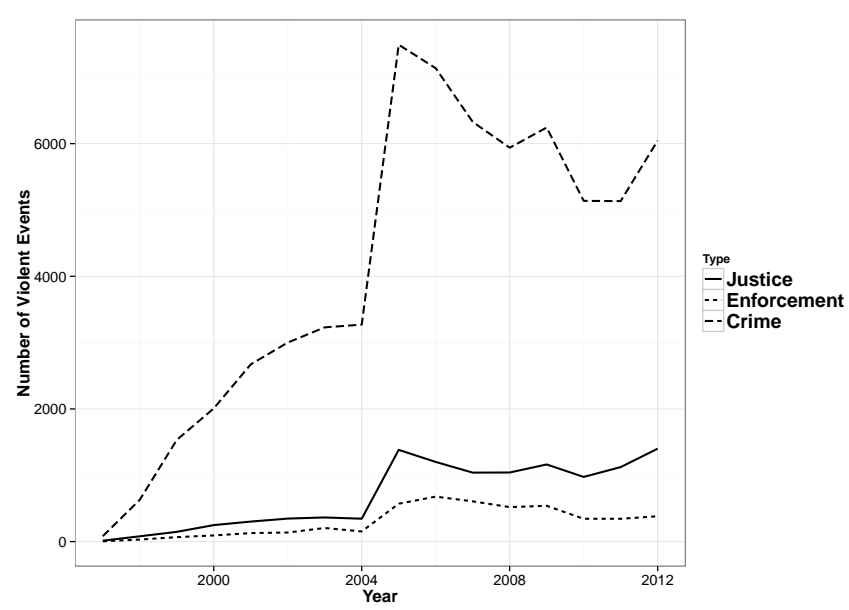

(b)

Figure 3: Number of Violent Events by Type.

The data also show variation in the type of violence found most commonly. Figure 3 depicts the evolution of different types of violence for the same time period. 
The figure visualizes the well-documented spike in identity-related violence in the time period from 1998 to 2004. Since 2004 there has been a clear increase in violence related to crime and resources. Moreover, the abating of identity related violence by 2004 has been followed by a gradual, but steady increase. Violence related to elections and governance has been on the rise - most likely due to political conflicts over electoral contests at the district level and associated service provision at the local level. ${ }^{13}$

To identify the main drivers of violent political conflict in Indonesian districts, we construct a time-series cross-sectional panel dataset based on the data provided through NVMS for the years 2001 to $2010 .^{14}$ This allows us to test the effects of decentralized governance, after its inception, on local forms of violence. For the purposes of our analysis we took the NVMS event data and aggregated the number of violent events to the district-year. As part of Indonesia's decentralization process the number and size of districts has dramatically changed over the period of study. To allow for maximum data coverage, we include all districts until the moment of a split. After a split, we assign new district codes to the "mother" and "daughter" districts and treat them as separate entities. This creates an unbalanced panel with entry and exit of units.

\subsection{Description of Main Independent Variables}

To explain variation in violence we use a number of relevant covariates. We start by focusing on our main independent variables of interest. To distinguish different dimensions of Indonesia's decentralization program, we include four distinct measures: the introduction of local direct district head elections, district splitting (changes in district boundaries), government revenues, and service delivery. We draw on data from the Ministry of Home Affairs to identify districts with directly elected district heads in the 2001-2010 time period. We construct a simple lagged dummy variable, taking the value of 1 if a district head has been directly elected. Importantly, it was decided

\footnotetext{
${ }^{13}$ There is a general uptick post-2004 in all forms of violence due to a better set of news sources from which the NVMS draws. We correct for this intercept shift in our analysis by including year effects.

${ }^{14}$ We excluded the years of 2011 and 2012 from the time series analysis for the following reason. Several of our indicators including the service delivery variables come from the Susenas, Indonesia's National Socio-Economic Survey. In 2011, BPS changed its sampling methods from using a two to a three stage sampling method. BPS also switched to using population weights from the 2010 population census for sampling procedures and it changed from implementing one annual survey to four quarterly surveys.
} 
that unlike local parliamentary elections, elections for the district head office would be phased-in. District heads appointed during the Suharto regime were allowed to finish their terms, at the end of which a new election was scheduled. From 1999 to 2004 district heads were then successively elected by local parliaments and starting in 2005 picked via direct elections. The staggered and exogenously determined schedule (Skoufias et al. 2014) provides strong causal identification for this variable and allows us to estimate the possible effect of this institutional change on local conflict.

To measure the effects of district creation, we include a dummy variable indicating whether a district was newly created after 2001. The splitting of existing districts, reflects the desire of local ethnic groups to create a more homogenous administrative unit and the desire of local elites to capture government resources (Fitrani, Hofman and Kaiser 2005, Kimura 2013).

We also include the log of total district government revenue per capita (DAPOER, MoF) to measure the fiscal dimension of decentralization. As a robustness check, we also examine the relationship of three sources of government revenue on violence: General Block Grants (DAU); own source revenues (PAD) that are obtained through local taxes and levies, as well as the profits from local state-owned enterprises; and natural resource revenue.

As a measure of decentralized public service delivery, we include a simple, standardized additive index of public service delivery consisting of access to sanitation, safe water, average enrollment rates in primary and junior secondary school, and births attended by skilled personnel. Each of these services are under the jurisdiction of local governments (Lewis, McCulloch and Sacks 2015). ${ }^{15}$ We also include three alternative measures for robustness checks. First, we include the quality of district roads in the index. Because the data on district roads is only available from 2003, we excluded it from the index for the main results. Second, we estimated a model with each of the individual index components. Third, following Anderson (2008), we estimated a model with a summary index, which is a weighted mean of several standardized outcomes in which the weights — the inverse of the covariance matrix - are used to maximize the amount of information captured by the index. ${ }^{16}$.

\footnotetext{
${ }^{15}$ Within Indonesia, the relationship between fiscal transfers and service delivery is not straightforward. While the central government tends to transfer more fiscal resources to districts with weak service delivery, these revenues are associated with deteriorating outcomes in districts with particularly poor service delivery (Lewis 2014).

${ }^{16}$ Using a summary index ensures that the probability of a false rejection does not increase as additional items
} 


\subsection{Description of Control Variables}

We include as controls variables including logged population size (DAPOER), ${ }^{17}$ whether the district is urban or rural, population density and logged GDP per capita (DAPOER). Poor and densely populated areas are more likely to experience various forms of political violence. We distinguish GDP generated by the oil and gas sector and remaining GDP. GDP derived from the natural resource sector might be associated with more conflict. We also control for socio-economic outcomes like logged poverty counts and morbidity levels (DAPOER). Moreover, we include a standard measure of ethnic linguistic fractionalization (ELF) from the 2000 and 2010 census to account for ethnic grievances and a dummy variable indicating whether the largest ethnic group represents $50 \%$ or more of the total population. ${ }^{18}$ To trace the effect of potential economic-based grievances on violence at the local level, we include a Gini index of household consumption-based local income inequality (World Bank). Summary statistics for all variable are presented in the Appendix.

\section{Results}

Since our outcome of interest is a non-negative count of violent events, we estimate negative binomial regression models. These are standard generalized linear models used for counts that also address potential problems due to over-dispersion in the distribution of events. To account for heteroskedasticity and arbitrary serial correlation we cluster standard errors at the district level. We report regression coefficients and robust standard errors in our tables. Standard significance levels are based on familiar p-values and large sample inference.

are added to the index, and minimizes the risk that researchers over-interpret individual proxy measures that may be statistically significant due simply to random chance.

\footnotetext{
${ }^{17}$ Urbanization is likely to play an important role in explaining levels of violence in Indonesia. We explore this issue further by also considering specifications that include a squared term of the population count (see Section 20 in the Appendix for details). These models suggest that especially mid-sized towns are, on average, more likely to experience violence.

${ }^{18}$ Districts existing in 2001 receive a ethnic fractionalization score and ethnic majority status based on the 2000 census, newly created districts, not covered by the 2000 census, are assigned fractionalization scores from the 2010 census. In Section 21 of the Appendix we also present results from regressions that additionally control for religious fractionalization of the district. This does not change any of our main findings. Moreover, religious and ethnic fractionalization correlate fairly strongly $(0.49)$.
} 
Table 1 presents our main results, while Figure 4 illustrates the substantive importance of our main variables of interest. ${ }^{19}$

Table 1: Determinants of Violence, Negative Binomial, Main Results

\begin{tabular}{|c|c|c|c|c|c|c|c|c|}
\hline & $\begin{array}{c}(1) \\
\text { Total }\end{array}$ & $\begin{array}{c}(2) \\
\text { Resources }\end{array}$ & $\begin{array}{c}(3) \\
\text { Governance }\end{array}$ & $\begin{array}{c}(4) \\
\text { Election }\end{array}$ & $\begin{array}{c}(5) \\
\text { Identity }\end{array}$ & $\begin{array}{c}(6) \\
\text { Justice }\end{array}$ & $\begin{array}{c}(7) \\
\text { Enforcement }\end{array}$ & $\begin{array}{c}(8) \\
\text { Crime }\end{array}$ \\
\hline Urban & $\begin{array}{c}1.170^{* * *} \\
(0.215)\end{array}$ & $\begin{array}{c}1.109^{* * *} \\
(0.302)\end{array}$ & $\begin{array}{c}1.060^{* * * *} \\
(0.255)\end{array}$ & $\begin{array}{l}0.847^{* *} \\
(0.293)\end{array}$ & $\begin{array}{l}1.921^{* * *} \\
(0.443)\end{array}$ & $\begin{array}{l}1.637^{* * *} \\
(0.280)\end{array}$ & $\begin{array}{c}1.012^{* * *} \\
(0.257)\end{array}$ & $\begin{array}{c}1.128^{* * *} \\
(0.225)\end{array}$ \\
\hline log Population & $\begin{array}{c}0.739^{* * *} \\
(0.223)\end{array}$ & $\begin{array}{l}0.0519 \\
(0.256)\end{array}$ & $\begin{array}{c}0.315 \\
(0.229)\end{array}$ & $\begin{array}{l}-0.158 \\
(0.290)\end{array}$ & $\begin{array}{c}0.670 \\
(0.439)\end{array}$ & $\begin{array}{l}0.760^{* *} \\
(0.254)\end{array}$ & $\begin{array}{l}0.691^{* *} \\
(0.255)\end{array}$ & $\begin{array}{l}0.806^{* *} \\
(0.250)\end{array}$ \\
\hline $\log$ GDP pc (No Oil) & $\begin{array}{l}0.352^{* * *} \\
(0.0885)\end{array}$ & $\begin{array}{c}0.268 \\
(0.167)\end{array}$ & $\begin{array}{c}0.00485 \\
(0.135)\end{array}$ & $\begin{array}{l}-0.393^{*} \\
(0.163)\end{array}$ & $\begin{array}{c}-0.0308 \\
(0.223)\end{array}$ & $\begin{array}{c}0.527^{* * *} \\
(0.110)\end{array}$ & $\begin{array}{l}0.268^{*} \\
(0.111)\end{array}$ & $\begin{array}{l}0.406^{* * *} \\
(0.0866)\end{array}$ \\
\hline $\log$ Oil GDP pc & $\begin{array}{l}-0.181^{+} \\
(0.0937)\end{array}$ & $\begin{array}{c}-0.473^{* * *} \\
(0.105)\end{array}$ & $\begin{array}{c}-0.153 \\
(0.0945)\end{array}$ & $\begin{array}{c}0.00103 \\
(0.170)\end{array}$ & $\begin{array}{c}-0.914^{* * *} \\
(0.161)\end{array}$ & $\begin{array}{c}0.0201 \\
(0.0952)\end{array}$ & $\begin{array}{c}0.104 \\
(0.166)\end{array}$ & $\begin{array}{l}-0.219^{*} \\
(0.111)\end{array}$ \\
\hline Population Density & $\begin{array}{l}-0.0000882 \\
(0.0000571)\end{array}$ & $\begin{array}{c}-0.0000912 \\
(0.0000598)\end{array}$ & $\begin{array}{l}-0.0000979^{*} \\
(0.0000497)\end{array}$ & $\begin{array}{c}-0.000208^{* * *} \\
(0.0000467)\end{array}$ & $\begin{array}{c}-0.0000992 \\
(0.0000756)\end{array}$ & $\begin{array}{l}-0.000129^{*} \\
(0.0000516)\end{array}$ & $\begin{array}{c}-0.0000941 \\
(0.0000651)\end{array}$ & $\begin{array}{l}-0.0000849 \\
(0.0000600)\end{array}$ \\
\hline $\log$ Poverty & $\begin{array}{l}0.234^{*} \\
(0.103)\end{array}$ & $\begin{array}{l}0.396^{*} \\
(0.156)\end{array}$ & $\begin{array}{c}0.201 \\
(0.163)\end{array}$ & $\begin{array}{c}0.201 \\
(0.197)\end{array}$ & $\begin{array}{l}0.696^{+} \\
(0.375)\end{array}$ & $\begin{array}{c}0.149 \\
(0.147)\end{array}$ & $\begin{array}{c}0.135 \\
(0.153)\end{array}$ & $\begin{array}{l}0.218^{*} \\
(0.109)\end{array}$ \\
\hline Inequality & $\begin{array}{c}0.0137^{+} \\
(0.00817)\end{array}$ & $\begin{array}{c}0.0180 \\
(0.0128)\end{array}$ & $\begin{array}{c}0.0132 \\
(0.0111)\end{array}$ & $\begin{array}{l}0.0332^{*} \\
(0.0139)\end{array}$ & $\begin{array}{c}0.0227 \\
(0.0201)\end{array}$ & $\begin{array}{l}0.0297^{* *} \\
(0.0113)\end{array}$ & $\begin{array}{c}-0.0139 \\
(0.00990)\end{array}$ & $\begin{array}{c}0.0141 \\
(0.00907)\end{array}$ \\
\hline Morbidity & $\begin{array}{l}-0.00387 \\
(0.00438)\end{array}$ & $\begin{array}{c}0.00648 \\
(0.00637)\end{array}$ & $\begin{array}{c}0.0129^{*} \\
(0.00515)\end{array}$ & $\begin{array}{l}-0.00409 \\
(0.00768)\end{array}$ & $\begin{array}{l}0.00931 \\
(0.0129)\end{array}$ & $\begin{array}{l}-0.0116^{+} \\
(0.00638)\end{array}$ & $\begin{array}{l}-0.00779 \\
(0.00744)\end{array}$ & $\begin{array}{l}-0.00470 \\
(0.00485)\end{array}$ \\
\hline Ethnic Fractionalization & $\begin{array}{l}0.0711 \\
(0.277)\end{array}$ & $\begin{array}{l}-0.430 \\
(0.383)\end{array}$ & $\begin{array}{l}-0.550 \\
(0.364)\end{array}$ & $\begin{array}{l}-0.469 \\
(0.470)\end{array}$ & $\begin{array}{c}0.395 \\
(0.824)\end{array}$ & $\begin{array}{l}-0.759^{*} \\
(0.322)\end{array}$ & $\begin{array}{l}-0.202 \\
(0.324)\end{array}$ & $\begin{array}{c}0.185 \\
(0.298)\end{array}$ \\
\hline Ethnic Majority & $\begin{array}{l}-0.291^{*} \\
(0.135)\end{array}$ & $\begin{array}{c}-0.672^{* * *} \\
(0.187)\end{array}$ & $\begin{array}{l}-0.267 \\
(0.170)\end{array}$ & $\begin{array}{l}-0.347 \\
(0.271)\end{array}$ & $\begin{array}{l}-0.201 \\
(0.348)\end{array}$ & $\begin{array}{c}-0.566^{* * *} \\
(0.162)\end{array}$ & $\begin{array}{l}-0.283 \\
(0.178)\end{array}$ & $\begin{array}{r}-0.267^{+} \\
(0.145)\end{array}$ \\
\hline Elected Leader & $\begin{array}{l}-0.195^{*} \\
(0.0843)\end{array}$ & $\begin{array}{c}-0.102 \\
(0.132)\end{array}$ & $\begin{array}{l}0.0818 \\
(0.107)\end{array}$ & $\begin{array}{c}0.506^{* * *} \\
(0.147)\end{array}$ & $\begin{array}{c}0.153 \\
(0.272)\end{array}$ & $\begin{array}{c}0.118 \\
(0.121)\end{array}$ & $\begin{array}{l}0.0647 \\
(0.101)\end{array}$ & $\begin{array}{l}-0.292^{* *} \\
(0.0893)\end{array}$ \\
\hline Newly Created District & $\begin{array}{l}-0.364^{*} \\
(0.144)\end{array}$ & $\begin{array}{c}-0.667^{* * *} \\
(0.192)\end{array}$ & $\begin{array}{c}-0.326^{+} \\
(0.187)\end{array}$ & $\begin{array}{l}-0.210 \\
(0.235)\end{array}$ & $\begin{array}{c}-1.546^{* * *} \\
(0.349)\end{array}$ & $\begin{array}{c}-0.414^{*} \\
(0.167)\end{array}$ & $\begin{array}{c}-0.289^{+} \\
(0.154)\end{array}$ & $\begin{array}{l}-0.373^{*} \\
(0.153)\end{array}$ \\
\hline $\log$ Total Revenue pc & $\begin{array}{c}0.132 \\
(0.210)\end{array}$ & $\begin{array}{c}-0.246 \\
(0.326)\end{array}$ & $\begin{array}{c}0.207 \\
(0.225)\end{array}$ & $\begin{array}{l}-0.377 \\
(0.289)\end{array}$ & $\begin{array}{l}1.021^{*} \\
(0.401)\end{array}$ & $\begin{array}{l}-0.229 \\
(0.265)\end{array}$ & $\begin{array}{l}-0.470^{*} \\
(0.231)\end{array}$ & $\begin{array}{c}0.191 \\
(0.226)\end{array}$ \\
\hline Service Provision & $\begin{array}{l}0.125^{* * *} \\
(0.0269)\end{array}$ & $\begin{array}{c}0.107^{*} \\
(0.0431)\end{array}$ & $\begin{array}{l}0.0858^{* *} \\
(0.0270)\end{array}$ & $\begin{array}{l}0.171^{* * *} \\
(0.0365)\end{array}$ & $\begin{array}{c}0.117^{*} \\
(0.0528)\end{array}$ & $\begin{array}{l}0.0625^{+} \\
(0.0372)\end{array}$ & $\begin{array}{l}0.0698^{* *} \\
(0.0256)\end{array}$ & $\begin{array}{l}0.130^{* * *} \\
(0.0290)\end{array}$ \\
\hline Constant & $\begin{array}{l}-10.59^{*} \\
(5.047) \\
\end{array}$ & $\begin{array}{l}-1.295 \\
(7.150) \\
\end{array}$ & $\begin{array}{r}-9.408^{+} \\
(5.170) \\
\end{array}$ & $\begin{array}{c}5.270 \\
(6.681) \\
\end{array}$ & $\begin{array}{c}-32.32^{* * *} \\
(9.393) \\
\end{array}$ & $\begin{array}{l}-7.224 \\
(5.992) \\
\end{array}$ & $\begin{array}{c}-2.063 \\
(5.576) \\
\end{array}$ & $\begin{array}{c}-12.55^{*} \\
(5.548) \\
\end{array}$ \\
\hline Over-Dispersion & $\begin{array}{c}-0.465^{* * *} \\
(0.0941)\end{array}$ & $\begin{array}{c}0.118 \\
(0.127)\end{array}$ & $\begin{array}{l}-0.174 \\
(0.131)\end{array}$ & $\begin{array}{c}0.798^{* * *} \\
(0.111)\end{array}$ & $\begin{array}{c}1.163^{* * *} \\
(0.201)\end{array}$ & $\begin{array}{l}-0.0647 \\
(0.127)\end{array}$ & $\begin{array}{c}-0.368^{* * *} \\
(0.105)\end{array}$ & $\begin{array}{c}-0.354^{* * *} \\
(0.0965)\end{array}$ \\
\hline $\begin{array}{l}\text { Observations } \\
\text { Log-Likelihood }\end{array}$ & $\begin{array}{c}915 \\
-3917.9\end{array}$ & $\begin{array}{c}915 \\
-1432.3\end{array}$ & $\begin{array}{c}915 \\
-1242.6\end{array}$ & $\begin{array}{c}915 \\
-1078.1\end{array}$ & $\begin{array}{c}915 \\
-882.1\end{array}$ & $\begin{array}{c}915 \\
-1934.1\end{array}$ & $\begin{array}{c}915 \\
-1591.9\end{array}$ & $\begin{array}{c}915 \\
-3632.6\end{array}$ \\
\hline AIC & 7867.8 & 2896.7 & 2517.1 & 2188.1 & 1796.2 & 3900.1 & 3215.9 & 7297.1 \\
\hline
\end{tabular}

${ }^{19}$ Figure 4 shows the simulated average effects and associated $95 \%$ confidence intervals, based on the estimates in Model 1 of Table 1 . All other variables were set at their respective means. Simulation were implemented via the Clarify routine in Stata. Given the average of approximately 50 violent events per district-year, each of the variables displayed in Figure 4 has substantive significance. 


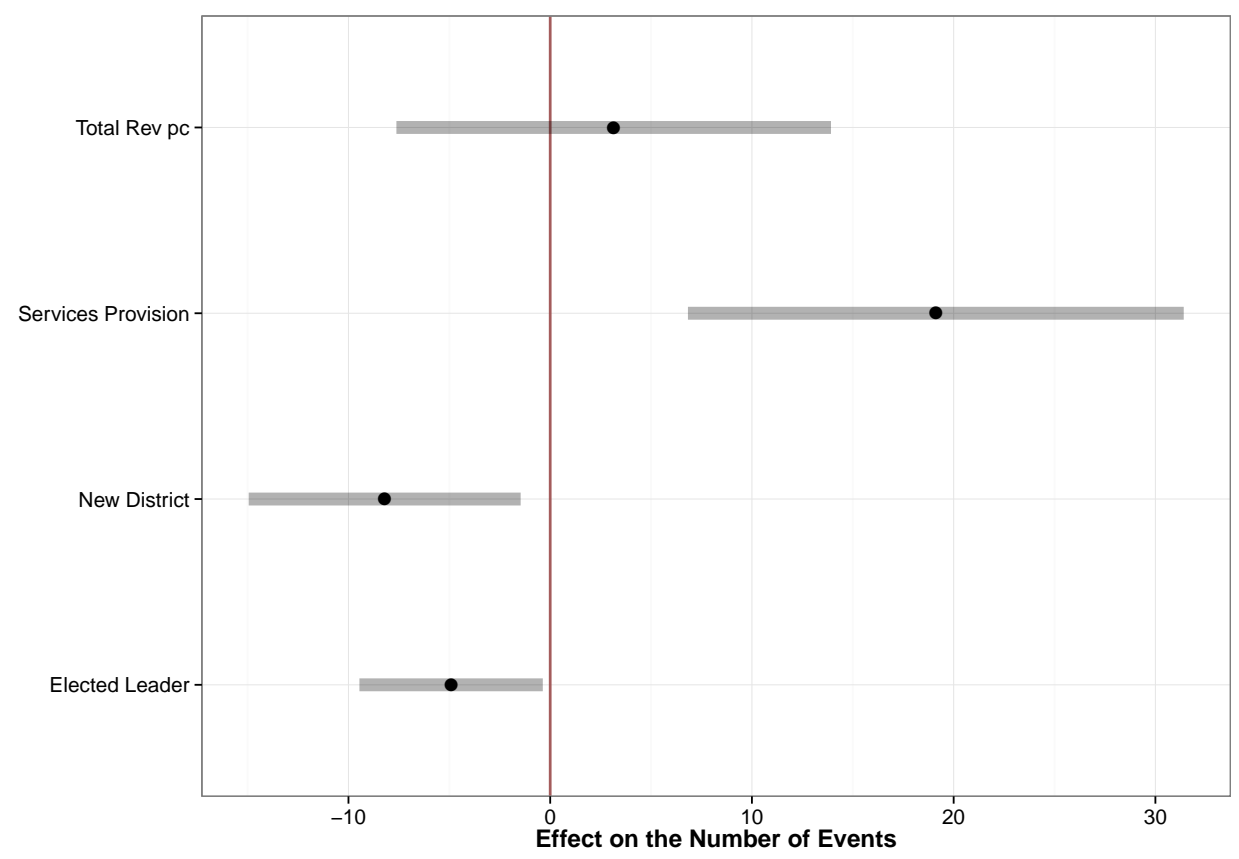

Figure 4: Substantive Effects for a Change from the 25th to 75th Percentile or 0 to 1 for Binary Variables

We find a number of noteworthy patterns. Districts with directly elected leaders feature overall lower levels of violence. ${ }^{20}$ This might be related to improved representation and the willingness of electorally accountable district heads to address local grievances and manage local group conflict peacefully. However, having an elected district head has a statistically significant and positive effect on electoral violence. This is likely due to the violent contestation of results in some contexts, where local groups are competing for the control of resources and entrenched incumbents use established power structures to disadvantage opposition candidates. This suggests support for both Hypotheses 1a and $1 \mathrm{~b}$, depending on the type of local violence.

One of the stronger findings pertains to the re-drawing of district boundaries. Newly created districts are much less likely to experience a large number of violent events, as well as most of the other types of violence. This mirrors recent qualitative assessments on the role of district proliferation for the "non-violent renaissance of local identities" (Mietzner 2014). It might be the case that the finding is driven by spikes of violence in the time period leading up to district

\footnotetext{
${ }^{20}$ We also tested for the presence of election year effects (see Section 3 in the Online Appendix). Election-related violence spikes during election years, but does not diminish the overall effect of elected local leaders.
} 
splits (Nolan, Jones and Solahudin 2014). This does not systematically seem to be the case. For one, the results are robust to including lagged levels of violence as a control (see Section 19 in the Appendix) and violence in itself is not predictive of district splits (Pierskalla 2016). Overall, the effects of district creation are more in line with Hypothesis 2a.

Total revenue per capita is associated with identity-related violence and the direction of the association is positive, suggesting that local groups might be competing for access (Hypothesis $3 \mathrm{~b}$ ). At the same time, districts with higher fiscal transfers record a lower number of law enforcementrelated violent events. One possible explanation for the paucity of findings is that the transfers themselves are a function of violence. Moreover, once we exclude all districts from Papua ${ }^{21}$ from the analysis, the overall effect of government revenue turns negative and statistically significant for total and most of the other types of violence, excluding identity-related violence (see Section 4 in the Online Appendix). This suggests that the political conflicts generated by fiscal transfers to local governments unfold according to a different logic on and off Papua. Off-Papua, fiscal transfers are mitigating conflict (Hypothesis 3a) and on-Papua, there is no correlation between fiscal transfers and violence. We further investigate the overall effects of local revenue for the complete sample by distinguishing between resource, own tax and DAU revenue per capita, without finding any clear patterns (see Section 5 in the Online Appendix).

Somewhat surprisingly, we find a highly significant and positive effect of service provision on all types of violence. This speaks against the basic expectation that improvements in public services ameliorate grievances and increases the opportunity costs for violence. Rather, the positive association is consistent with the literature which suggests that when development is accompanied by rising expectations and inequitable access to services, conflicts may emerge (Cederman, Weidmann and Gleditsch 2011, Tadjoeddin 2014). The distributive channel is further supported by the fact that an interaction between service delivery and ethnic fractionalization is also found to be significant. If better public service delivery creates increased group conflict over access to services or due to newly emerging distributive struggles, we would expect the effect of service delivery to be larger in more heterogenous localities. As illustrated in Figure 5, this is exactly what we find in the data: more heterogenous districts feature a stronger positive association between service delivery and

\footnotetext{
${ }^{21}$ Here we refer to districts from both West and East Papua province.
} 
violence. The relationship is weaker (but still positive and significant) in more homogenous areas. The difference between these two scenarios is also statistically significant in itself. Moreover, an interaction with the ethnic majority variable reveals that for districts dominated by a single group the positive effect of service delivery is diminished. Together, these findings suggest that conflict over access to services is most likely to erupt when several, similarly sized groups are competing with each other, whereas the dominance of one group starkly limits the outbreak of violence.

One might worry that this finding is not necessarily about conflict over public service provision, but instead captures violence that erupts over the size of and control over the local bureaucracy. Potentially, district with higher levels of service provision also have larger bureaucracies, which might generate conflict over patronage opportunities. This does not seem to be the case. When we add as an additional control the number of civil servants per capita in the district, we still find a positive and statistically effect of the service delivery measure (see Section 7 in the Online Appendix). ${ }^{22}$

The positive association between service delivery and violence is supported by additional checks. When we also include the square of the public service index, we find that across nearly all forms of violence the relationship follows an inverted U-shape (see Section 7 in the Online Appendix). This is consistent with a story of exclusion, where violence is fairly low when public service is low to non-existent. As service delivery improves, local governments can offer access to highly valued club goods to some, but not all local citizens, which generates resentment and grievances, generating an association with higher levels of violence. As service delivery improves to even higher levels, access becomes more equitable and eventually reduces violence. These results complement prior findings on Indonesia (Diprose 2008b; 2009, Østby et al. 2011, Tadjoeddin 2014) and offer additional evidence that horizontal inequalities, which we measure in terms of access to government services, is crucial for understanding local forms of violence.

\footnotetext{
${ }^{22}$ Data on the number of civil servants was provided by the government of Indonesia for the years $2005-2012$. We also consider the number of civil servants per urban population to account for the fact that conflict around civil service patronage is more relevant for urban citizens. This does not affect our findings.
} 


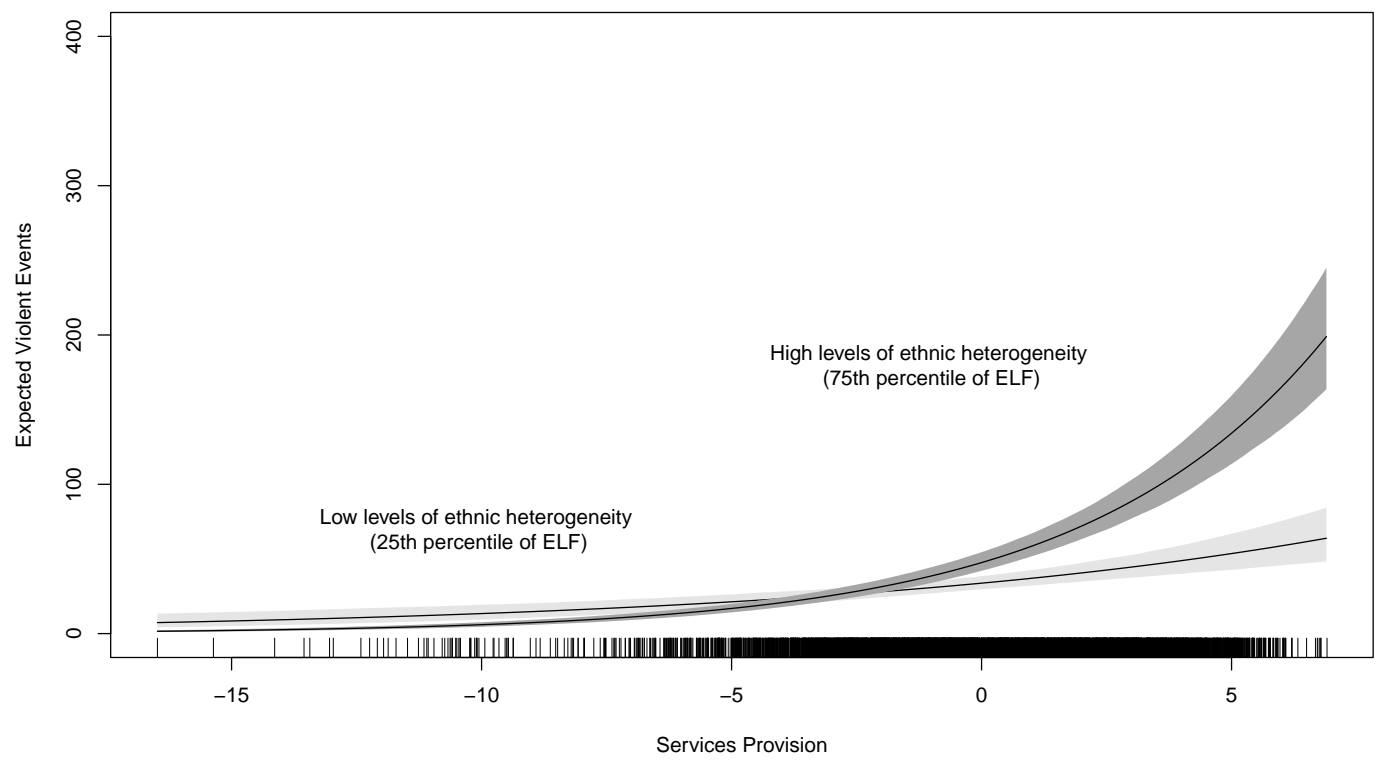

Figure 5: Interaction of Ethnic Linguistic Diversity and Public Service Delivery on Violence when Changing ELF from the 25th to 75th Percentile

\subsection{Additional Robustness Checks}

In general, the results that are displayed in Table 1 and Figure 4 are robust to the inclusion of a polynomial time trend, a full set of year dummies, or dummies for the main islands or provinces and spatial lags (see Sections 8-12 in the Online Appendix).

Section 13 in the Appendix discusses in detail concerns about the method in which the NVMS was collected. While Section 14 in the Online Appendix discusses in detail the issue of potential reporting bias, we want to highlight one specific finding. Since newspapers are more likely to report events if deaths occurred, we also construct a set of event counts for each district-year that only includes events with at least one fatality. We then repeat all estimations in Table 1, using this new event count, largely confirming our main findings. Focusing on fatality-only events is also important in order to check whether the patterns of violence differ dramatically between violent and non-violent events. Our results from this robustness check suggest that this is not the case with respect to the different dimensions of decentralized governance.

With respect to our finding on service delivery it is also possible that the proposed causality is 
reversed: violence attracts an increase in resources for public service delivery, such as development aid. To test for this possibility we first take service delivery as our dependent variable and include our violence measures as explanatory variables (Section 15 in the Online Appendix). We find little evidence that lagged violence affects levels of service delivery. We also test for Granger causality and find clear evidence that lagged public service delivery granger causes violence, but not the other way around. One might also be concerned about potential endogeneity being induced by including fiscal transfer variable at the same time as our services measure - additional models in Section 16 in the Online Appendix show that this does not affect our findings.

More generally, there could also be an issue of unobserved confounders at the district level. To address this concern, we start by estimating the models in Table 1, but instead of including the level of service provision, we estimate the effect for the year-to-year change in service provision. Here we find that an increase in service provision is associated with higher levels of violence for governance and election-related violence (see Section 17 in the Appendix).

We explore this finding in more detail using a correlated random effects model (Gelman and Hill 2008, Bell and Jones 2015). ${ }^{23}$ For a correlated random effects model we include random effects for each district as well as decompose each variable in our model into their "within" and "between" variation components. The "between" part of the variation for each variable measures the mean level over time, whereas as the "within" part captures over-time deviations from that mean. Decomposing each variable in this way has the advantage of conceptually distinguishing between the sources of the effects identified in Table 1. Moreover, the time-invariant "between" parts of each variable play a similar role as standard fixed effects. The "between" variables will affect the means of the random effects for each district and account for unobserved, time-invariant factors. Hence, the "within" part of each variable is identified just as in a standard fixed effects model, while not sacrificing the efficiency gains of the random effects approach (Bell and Jones 2015).

Table 2 shows the coefficients for our main variables of interest from the correlated random effects model. The model also includes our initial set of controls, the number of civil servants per capita in order to distinguish a service provision channel from the mere size of the bureaucracy, and a

\footnotetext{
${ }^{23}$ Standard fixed effects models encounter the incidental parameters problem in negative binomial models.
} 
linear time trend. The table indicates that a substantial component of the positive and statistically significant effect of public service delivery on conflict is driven by cross-sectional variation. Across six of the eight models the "between" variation has a positive and highly statistically significant effect. While in line with our prior findings, this coefficient is also likely to be affected to some extent by omitted variable bias. Unobserved district characteristics could affect mean levels of service provision and levels of violence simultaneously. The "within" component reveals a much more nuanced pattern. For popular justice related violence over-time improvements in service delivery reduce incidents of violence. At the same time, improvements in service delivery are positively associated with governance and identity-related violence, statistically significant below the $0.1 \%$ and $5 \%$ level respectively. This latter finding supports the notion that the positive association between improved service delivery and violence is due to group-level conflicts over access and control of district resources.

The other decentralization variables are mostly similar to the findings from Table 1 . New districts experience generally less violence, although the effect is only statistically significant at conventional levels for identity related violence. Direct elections are associated with more electionrelated violence for the 'between' component, but actually experience less electoral violence when looking at within-district variation. Total revenue per capita is still largely insignificant for the whole sample, but is associated with reductions for at least some types of violence for increases within districts over time. 
Table 2: Determinants of Violence, Correlated Random Effects Negative Binomial

\begin{tabular}{|c|c|c|c|c|c|c|c|c|}
\hline & $\begin{array}{c}(1) \\
\text { Total }\end{array}$ & $\begin{array}{c}(2) \\
\text { Resources }\end{array}$ & $\begin{array}{c}(3) \\
\text { Governance }\end{array}$ & $\begin{array}{c}(4) \\
\text { Election }\end{array}$ & $\begin{array}{c}5) \\
\text { Identity }\end{array}$ & $\begin{array}{c}6) \\
\text { Justice }\end{array}$ & $\begin{array}{c}(7) \\
\text { Enforcement }\end{array}$ & $\begin{array}{c}(8) \\
\text { Crime } \\
\end{array}$ \\
\hline Services Provision (Between) & $\begin{array}{l}0.0471^{+} \\
(0.0271)\end{array}$ & $\begin{array}{c}0.134^{* *} \\
(0.0467)\end{array}$ & $\begin{array}{c}0.0424 \\
(0.0416)\end{array}$ & $\begin{array}{c}0.113^{*} \\
(0.0495)\end{array}$ & $\begin{array}{l}-0.0385 \\
(0.0735)\end{array}$ & $\begin{array}{c}0.118^{* *} \\
(0.0420)\end{array}$ & $\begin{array}{c}0.106^{* *} \\
(0.0376)\end{array}$ & $\begin{array}{l}0.0728^{*} \\
(0.0288)\end{array}$ \\
\hline Services Provision (Within) & $\begin{array}{c}0.0159 \\
(0.0198)\end{array}$ & $\begin{array}{l}-0.0212 \\
(0.0509)\end{array}$ & $\begin{array}{l}0.198^{* * *} \\
(0.0564)\end{array}$ & $\begin{array}{c}0.0687 \\
(0.0756)\end{array}$ & $\begin{array}{c}0.179^{*} \\
(0.0871)\end{array}$ & $\begin{array}{l}-0.0677^{*} \\
(0.0340)\end{array}$ & $\begin{array}{c}0.0427 \\
(0.0423)\end{array}$ & $\begin{array}{r}-0.00513 \\
(0.0216)\end{array}$ \\
\hline log Total Revenue pc (Between) & $\begin{array}{l}-0.285 \\
(0.282)\end{array}$ & $\begin{array}{l}-0.390 \\
(0.453)\end{array}$ & $\begin{array}{c}0.106 \\
(0.405)\end{array}$ & $\begin{array}{c}0.174 \\
(0.474)\end{array}$ & $\begin{array}{l}1.708^{*} \\
(0.676)\end{array}$ & $\begin{array}{l}0.0729 \\
(0.404)\end{array}$ & $\begin{array}{l}-0.433 \\
(0.379)\end{array}$ & $\begin{array}{c}-0.201 \\
(0.301)\end{array}$ \\
\hline log Total Revenue pc (Within) & $\begin{array}{r}-0.0762 \\
(0.114)\end{array}$ & $\begin{array}{r}-0.0874 \\
(0.270)\end{array}$ & $\begin{array}{c}0.149 \\
(0.286)\end{array}$ & $\begin{array}{c}-0.834^{*} \\
(0.402)\end{array}$ & $\begin{array}{c}0.353 \\
(0.520)\end{array}$ & $\begin{array}{r}-0.449^{*} \\
(0.186)\end{array}$ & $\begin{array}{c}0.292 \\
(0.237)\end{array}$ & $\begin{array}{r}-0.0216 \\
(0.125)\end{array}$ \\
\hline Elected Leader (Between) & $\begin{array}{c}-0.0514 \\
(0.246)\end{array}$ & $\begin{array}{c}0.368 \\
(0.402)\end{array}$ & $\begin{array}{l}-0.162 \\
(0.404)\end{array}$ & $\begin{array}{l}1.185^{*} \\
(0.478)\end{array}$ & $\begin{array}{l}0.0939 \\
(0.621)\end{array}$ & $\begin{array}{c}0.569 \\
(0.365)\end{array}$ & $\begin{array}{c}0.511 \\
(0.334)\end{array}$ & $\begin{array}{l}0.0845 \\
(0.262)\end{array}$ \\
\hline Elected Leader (Within) & $\begin{array}{c}0.0996^{*} \\
(0.0486)\end{array}$ & $\begin{array}{l}0.247^{*} \\
(0.125)\end{array}$ & $\begin{array}{l}0.0758 \\
(0.139)\end{array}$ & $\begin{array}{l}-0.466^{*} \\
(0.202)\end{array}$ & $\begin{array}{c}0.187 \\
(0.206)\end{array}$ & $\begin{array}{c}0.167^{*} \\
(0.0812)\end{array}$ & $\begin{array}{l}0.0504 \\
(0.101)\end{array}$ & $\begin{array}{l}0.0906^{+} \\
(0.0531)\end{array}$ \\
\hline Newly Created District & $\begin{array}{r}-0.0763 \\
(0.138) \\
\end{array}$ & $\begin{array}{l}-0.303 \\
(0.223) \\
\end{array}$ & $\begin{array}{l}-0.145 \\
(0.214) \\
\end{array}$ & $\begin{array}{l}-0.234 \\
(0.251) \\
\end{array}$ & $\begin{array}{c}-1.405^{* * *} \\
(0.417)\end{array}$ & $\begin{array}{r}-0.0206 \\
(0.201) \\
\end{array}$ & $\begin{array}{r}-0.0829 \\
(0.185) \\
\end{array}$ & $\begin{array}{r}-0.0610 \\
(0.146)\end{array}$ \\
\hline Linear Time Trend & $\checkmark$ & $\checkmark$ & $\checkmark$ & $\checkmark$ & $\checkmark$ & $\checkmark$ & $\checkmark$ & $\checkmark$ \\
\hline Observations & 745 & 745 & 745 & 745 & 745 & 745 & 745 & 745 \\
\hline Log-Likelihood & -2892.1 & -1055.9 & -988.5 & -855.0 & -637.2 & -1441.3 & -1226.6 & -2659.7 \\
\hline AIC & 5844.2 & 2171.7 & 2036.9 & 1770.1 & 1334.3 & 2942.6 & 2513.3 & 5379.5 \\
\hline
\end{tabular}


The final test for our service delivery findings uses an instrumental variable strategy. We argue that the age of a district is a good predictor of the quality of services, in part, because younger districts still need to build-up sufficient administrative capacity, but has little direct effect on levels of violence, given our set of control variables. We estimate a standard two-stages least squares instrumental variable model (2SLS) and find again evidence for a positive association between the level of service provision and violence (see Section 18 in the Appendix) ${ }^{24}$

\section{Conclusion}

Our findings shed new light on the ongoing discourse about violence in Indonesia and inform several larger theoretical debates about decentralization and decentralized governance. A number of interesting findings stand out. First, the results suggest that political reforms - the introduction of direct head elections and district splitting — both mitigate violence with one exception; the introduction of direct head elections is positively correlated with election-related violence. The creation of new districts seems to have mitigated identity-related violence at the local level, although additional research is needed to further substantiate this finding. Second, the relationship between fiscal transfers and violence is less clear. Off-Papua it seems fiscal transfers mitigate communal violence. Third and most interestingly, results point to a fairly robust, positive association between access to public services and violence. This effect is largely driven by cross-sectional variation, but also applies to over-time changes when it comes to identity and governance-related violence. We argue this finding is plausibly driven by horizontal competition between ethnic groups over access and control of government resources. These findings are consistent with prior, Indonesia-specific work (Diprose 2008b; 2009, Østby et al. 2011, Tadjoeddin 2014), but also speak to experiences with large-scale government programs in Indonesia. For example, Indonesia's government has experimented with a variety of reform programs including Raskin, a subsidized rice distribution program, PNPM Mandiri, a nation-wide community driven development project, $\mathrm{PKH}$, a conditional cash transfer program, as well as a host of other social assistance programs, with mixed results for conflict (e.g., Alatas et al. (2012), Sim, Negara and Suryahadi (2014)). When there was mis-targeting,

\footnotetext{
${ }^{24}$ The Kleibergen-Paap rk LM statistic indicates age of the district is a sufficiently strong instrument.
} 
BLT contributed to conflict, violence and an increase in crime (Cameron and Shah 2012). By contrast, Indonesia's national Community Driven Development Project known as PNPM, is an example of a project that mitigated the risk of conflict by integrating participatory processes and conflict resolution mechanisms into its design. The project's effective complaints handling mechanisms also defused tensions before they escalated (Barron, Diprose and Woolcock 2011). ${ }^{25}$ Putting these reform efforts into the context of our findings highlights the need for governments, donors, and other non-state actors to strongly consider issues of equitable access in public service delivery. Clearly, there is a need for additional quantitative and qualitative research efforts to investigate the exact mechanisms through which public service delivery is associated with violence.

\footnotetext{
${ }^{25} \mathrm{KDP}$ necessitates community involvement in deciding how KDP funds are spent on public services, primarily, tertiary infrastructure projects. Through encouraging the community including marginalized groups to play an active role in the collective decision making, KDP helped to prevent rather than promote conflict. In addition, KDP also contributed to greater inter-group relations at the village level with more marginalized groups attending non-project village meetings than in the past (Barron, Diprose and Woolcock 2011).
} 


\section{References}

Abuza, Zachary. 2007. Political Islam and Violence in Indonesia. Routledge.

Alatas, Vivi, Abhijit Banerjee, Rema Hanna, Benjamin A. Olken and Julia Tobias. 2012. "Targeting the Poor: Evidence from a Field Experiment in Indonesia." American Economic Review 102(4):1206-40.

Anderson, Michale L. 2008. "Multiple Inference and Gender Differences in the Effects of Early Intervention: A Reevaluation of the Abecedarian, Perry Preschool, and Early Training Projects." Journal of the American Statistical Association 103(484):1481-1495.

Aspinall, Edward. 2007. "The Construction of Grievance: Natural Resources and Identity in a Separatist Conflict." Journal of Conflict Resolution 51(6):950-104.

Aspinall, Edward. 2009. Islam and Nation. Separatist Rebellion in Aceh, Indonesia. Stanford University Press.

Bardhan, Pranab. 2002. "Decentralization of Governance and Development." Journal of Economic Perspectives 16(4):185-205.

Barron, Patrick and Joanne Sharpe. 2008. "Local Conflict in Post-Suharto Indonesia: Understanding Variations in Violence Levels and Forms Through Local Newspapers." Journal of East Asian Studies 8:395-423.

Barron, Patrick, Kai Kaiser and Menno Pradhan. 2009. "Understanding Variations in Local Conflict: Evidence and Implications from Indonesia." World Development 37(3):698-713.

Barron, Patrick, Rachael Diprose and Michael Woolcock. 2011. Contesting Development. Participatory Projects and Local Conflict Dynamics in Indonesia. Yale University Press.

Barron, Patrick, Sana Jaffrey and Ashutosh Varshney. 2014. "How Large Conflicts Subside: Evidence from Indonesia." The World Bank http://asiafoundation.org/resources/pdfs/ HowLargeConflictsSubside.pdf.

Bates, Robert H. 2008. "State Failure." Annual Review of Political Science 11:1-12. 
Beath, Andrew, Fotini Christia and Ruben Enikolopov. 2012. "Winning Hearts and Minds through Development? Evidence from a Field Experiment in Afghanistan." World Bank Policy Research Working Paper 6129 https://openknowledge.worldbank.org/bitstream/handle/ 10986/11950/WPS6129.pdf? sequence=1.

Bell, Andrew and Kelvyn Jones. 2015. "Explaining Fixed Effects: Random Effects modelling of Time-Series Cross-Sectional and Panel Data." Political Science Research and Methods 3(1):133153.

Berman, Eli, Jacob N. Shapiro and Joseph H. Felter. 2011. "Can Hearts and Minds Be Bought? The Economics of Counterinsurgency in Iraq." Journal of Political Economy 119(4):766-819.

Bertrand, Jacques. 2004. Nationalism and Ethnic Conflict in Indonesia. Cambridge University Press.

Brancati, Dawn. 2006. "Decentralization: Fueling the Fire or Dampening the Flames of Ethnic Conflict and Secessionism?" International Organization 60:651-685.

Brass, Paul R. 1991. Ethnicity and Nationalism: Theory and Comparison. Sage Publications.

Brown, Graham K. 2008. Horizontal Inequalities and Separatism in Southeast Asia: A Comparative Perspective. In Horizontal Inequalities and Conflict: Understanding Group Conflict in Multiethnic Societies, ed. Frances Stewart. Palgrave Macmillan chapter 12, pp. 252-277.

Brubaker, Rogers and David Laitin. 1998. "Ethnic and Nationalist Violence." Annual Review of Sociology 24(1):423-52.

Buehler, Michael and Paige Tan. 2007. "Party-Candidate Relationships in Indonesian Local Politics: A Case Study of the 2005 Regional Elections in Gowa, South Sulawesi Province." Indonesia 84:41-69.

Bunce, Valerie. 1999. Subversive Institutions: The Design and the Destruction of Socialism and the State. Cambridge University Press.

Cameron, Lisa and Manisha Shah. 2012. "Can Mistargeting Destroy Social Capital and Stimulate 
Crime? Evidence from a Cash Transfer Program in Indonesia." IZA DP No. 6736 http://ftp. iza.org/dp6736.pdf.

Cederman, Lars-Erik, Nils B. Weidmann and Kristian Skrede Gleditsch. 2011. "Horizontal Inequalities and Ethnonationalist Civil War: A Global Comparison." American Political Science Review 105(3):478-495.

Cohen, Margot. 2003. "New Indonesian Districts Radically Reshape Country." Far Eastern Economic Review 29 May.

Crost, Benjamin, Joseph Felter and Patrick Johnston. 2014. "Aid under Fire: Development Projects and Civil Conflict." American Economic Review 104(6):1833-56.

Crouch, Harold. 2010. Political Reform in Indonesia after Soeharto. ISEAS.

Davidson, Jamie S. 2008. From Rebellion to Riots: Collective Violence on Indonesian Borneo. The University of Wisconsin Press.

Davies, James. 1962. "Toward a theory of revolution." American Sociological Review 27(1):5-19.

Diprose, Rachael. 2008a. "Passing on the challenges or prescribing better management of diversity? Decentralisation, power sharing and conflict dynamics in Central Sulawesi, Indonesia." Conflict, Security \& Development 8(4):393-425.

Diprose, Rachael. 2009. "Decentralization, Horizontal Inequalities and Conflict Management in Indonesia." Ethnopolitics 8(1):107-134.

Diprose, Rachel. 2008b. "Passing on the challenges or prescribing better management of diversity? Decentralisation, power sharing and conflict dynamics in Central Sulawesi, Indonesia." Conflict, Security 8 Development 8(4).

Diprose, Rachel and Ukoha Ukiwo. 2008. "Decentralisation and Conflict Management in Indonesia and Nigeria." CRISE Working Paper No. 49.

Duncan, Christopher R. 2007. "Mixed Outcomes: The Impact of Regional Autonomy and Decentralization on Indigenous Ethnic Minorities in Indonesia." Development and Change 38(4):711733. 
Erb, Maribeth and Priyambudi Sulistiyanto, eds. 2009. Deepening Democracy in Indonesia? Direct Elections for Local Leaders (Pilkada). ISEAS.

Fearon, James D., Macartan Humphreys and Jeremy Weinstein. 2009. "Can Development Aid Contribute to Social Cohesion after Civil War? Evidence from a Field Experiment in PostConflict Liberia." American Economic Review: Papers and Proceedings 99(2):287-291.

Fitrani, Fitria, Bert Hofman and Kai Kaiser. 2005. "Unity in Diversity? The Creation of New Local Governments in a Decentralising Indonesia." Bulletin of Indonesian Economic Studies 41(1):57-79.

Ford, Michele. 2003. Who Are the Orang Riau? Negotiating Identity across Geographic and Ethnic Divides. In Local Power and Politics in Indonesia., ed. Edward Aspinall and Greg Fealy. Institute of Southeast Asian Studies pp. 194-216.

Gelman, Andrew and Jennifer Hill. 2008. Data Analysis Using Regression and Multilevel/Hierarchical Models. New York: Cambridge University Press.

Grossman, Guy and Janet I. Lewis. 2014. "Administrative Unit Proliferation." American Political Science Review 108(1):196-217.

Grossman, Herschel I. 1991. "A General Equilirium Model of Insurrections.” American Economic Review 81(4):912-921.

Gurr, Ted. 1970. Why Men Rebel. Princeton University Press.

Gurr, Ted. 2000. Peoples Versus States: Minorities at Risk in the New Century. U.S. Institute of Peace Press.

Hechter, Michael. 2000. Containing Nationalism. Oxford University Press.

Hofman, Bert and Kai Kaiser. 2004. The Making of the Big Bang and its Aftermath. A Political Economy Perspective. In Reforming Intergovernmental Fiscal Relations and the Rebuilding of Indonesia. The 'Big Bang' Program and its Economic Consequences, ed. James Alm, Jorge Martinez-Vazques and Sri Mulyani Indrawati. Edward Elgar chapter 2. 
Horowitz, Don. 1991. A Democratic South Africa? Constitutional Engineering in a Divided Society. University of California Press.

Horowitz, Donald L. 1985. Ethnic Groups in Conflict. University of California Press.

Juan, Alexander De, Jan H. Pierskalla and Johannes Vüllers. 2015. "The Pacifying Effects of Local Religious Institutions An Analysis of Communal Violence in Indonesia." Political Research Quarterly 68(2):211-224.

Kimura, Ehito. 2013. Political Change and Territoriality in Indonesia. Provincial Proliferation. Routledge.

Kymlicka, Will. 1998. Is Federalism a Viable Alternative to Secessionism? In Theories of Secessionism, ed. Percy B. Lehning. Routledge Press pp. 111-150.

Le Billon, Philippe. 2012. Wars of Plunder. Conflicts, Profits and The Politics of Resources. Columbia University Press.

Lewis, Blane. 2013. "Local Government Capital Spending in Indonesia: Impact of Intergovernmental Fiscal Transfers." Public Budgeting E Finance 33(1):76-94.

Lewis, Blane D. 2014. Twelve years of fiscal decentralization: a balance sheet. In Regional Dynamics in a Decentralized Indonesia, ed. Hal Hill. ISEAS.

Lewis, Blane, Neil McCulloch and Audrey Sacks. 2015. "Measuring Local Government Service Delivery: Challenges and (Partial) Solutions in Indonesia." Journal of International Development forthcoming.

Lijphart, Arend. 1977. Democracy in Plural Societies: A Comparative Exploration. Yale University Press.

Lijphart, Arend, Ronald Rogowski and Kent Weaver. 1993. Separation of Powers and Cleavage Management. In Do Institutions Matter? Brookings Institution Press.

Lujala, Päivi. 2009. "Deadly Combat over Natural Resources: Gems, Petroleum, Drugs, and the Severity of Civil Conflict." The Journal of Conflict Resolution 53(1):50-71. 
Lustik, Ian, Dan Miodownik and Roy J. Eidelson. 2004. "Secessionism in Multicultural States: Does Sharing Power Prevent or Encourage It?" American Political Science Review 98(2):209-229.

Mancini, Luca. 2008. Horizontal Inequality and Communal Violence: Evidence from Indonesian Districts. In Horizontal Inequalities and Conflict: Understanding Group Conflict in Multiethnic Societies, ed. Frances Stewart. Basingstoke: Palgrave Macmillan pp. 106-135.

McAdam, Doug, Sidney Tarrow and Charles Tilly. 2001. Dynamics of Contention. Cambridge University Press.

McRae, Dave. 2013. A Few Poorly Organised Men: Interreligious Violence in Poso, Indonesia. Brill.

Mietzner, Marcus. 2007. "Local Elections and Autonomy in Papua and Aceh: Mitigating or Fueling Secessionism?" Indonesia 84:1-39.

Mietzner, Marcus. 2014. Indonesia's decentralization: the rise of local identities and the survival of the nation-state. In Regional Dynamics in a Decentralized Indonesia, ed. Hal Hill. ISEAS chapter 3, pp. $45-67$.

Muller, Edward N. and Mitchell A. Seligson. 1987. "Inequality and Insurgency." American Political Science Review 81(2):425-452.

Murshed, Syed Mansoob, Mohammad Zulfan Tadjoeddin and Anis Chowdhury. 2009. "Is Fiscal Decentralization Conflict Abating? Routine Violence and Districts Level Government in Java, Indonesia." Oxford Development Studies 37(4):397-421.

Nolan, Cillian, Sidney Jones and Solahudin. 2014. The political impact of carving up Papua. In Regional Dynamics in a Decentralized Indonesia, ed. Hal Hill. ISEAS chapter 17, pp. 409-432.

Nordholt, Henk Schulte and Gerry van Klinken, eds. 2007. Renegotiating Boundaries. Local Politics in Post-Suharto Indonesia. KITLV Press.

O’Loughlin, John, Edward C. Holland and Frank D.W. Witmer. 2011. "The Changing Geography of Violence in Russia's North Caucasus, 1999-2011: Regiona Trends and Local Dynamics in 
Dagestan, Ingushetia, and Kabardino-Balkaria." Eurasian Geography and Economics 52(5):596630.

Østby, Gudrun, Henrik Urdal, Mohammed Zulfan Tadjoeddin, S. Mansoob Murshed and Håvard Strand. 2011. "Population Pressure, Horizontal Inequality and Political Violence: A Disaggregated Study of Indonesian Provinces, 1990-2003." Journal of Development Studies 47(3):377-398.

Panggabean, Samsu Rizal and Benjamin Smith. 2011. "Explaining Anti-Chinese Riots in Late 20th Century Indonesia." World Development 39(2):231-242.

Pierskalla, Jan H. and Florian M. Hollenbach. 2013. "Technology and Collective Action: The Effect of Cell Phone Coverage on Political Violence in Africa." American Political Science Review 107(2):207-224.

Pierskalla, Jan Henryk. 2016. "Splitting the Difference? The Politics of District Creation in Indonesia." Comparative Politics 48(2):249-268.

Posen, Barry. 1993. "The Security Dilemma and Ethnic Conflict." Survival 35(1):27-47.

Purdey, Jemma. 2006. Anti-Chinese Violence in Indonesia, 1996-1999. NUS Press.

Roeder, Philip G. 1991. "Soviet Federalism and Ethnic Mobilization." World Politics 43(2):196-232.

Saideman, Stephen M., David J. Lanoue, Michael Campenni and Samuel Stanton. 2002. "Democratization, Political Institutions, and Ethnic Conflict - A Pooled Time-Series Analysis, 1985-1998." Comparative Political Studies 35(1):103-129.

Schneider, Gerald and Nina Wiesehomeier. 2008. "Rules that matter. Political Institutions and the Diversity-Conflict Nexus." Journal of Peace Research 45(2):183-203.

Selway, Joel and Kharis Templeman. 2012. "The Myth of Consociationalism? Conflict Reduction in Divided Societies." Comparative Political Studies 45(12):1542-1571.

Sidel, John. 2006. Riots, pogroms, jihad: religious violence in Indonesia. Cornell University Press.

Sim, Armand, Radi Negara and Asep Suryahadi. 2014. "Inequality, Elite Capture, and Targeting of Social Protection Programs: Evidence from Indonesia." SMERU Working Paper http://smeru . or.id/report/workpaper/inequalitytargeting/inequalitytargeting.pdf. 
Skoufias, Emmanuel, Ambar Narayan, Basab Dasgupta and Kai Kaiser. 2014. "Electoral Accountability and Local Government Spending in Indonesia." World Bank Policy Research Working Paper 5614 http://elibrary.worldbank.org/doi/book/10.1596/1813-9450-6782.

Smith, Benjamin. 2008. "The Origins of Regional Autonomy in Indonesia: Experts and the Marketing of Political Interest." Journal of East Asian Studies 8(2):211-34.

Snyder, Jack L. 2000. From Voting to Violence: Democratization and Nationalist Conflict. New York, NY: W. W. Norton.

Suberu, Rotimi. 2001. Federalism and Ethnic Conflict in Nigeria. U.S. Institute of Peace Press.

Tadjoeddin, Mohammad Zulfan. 2002. "Anatomy of Social Violence in the Context of Transition: The Case of Indonesia 1990-2001." Politics Administration and Change 38(July-December):1-35.

Tadjoeddin, Mohammad Zulfan. 2014. Explaining Collective Violence in Contemporary Indonesia. Palgrave Macmillan.

Tadjoeddin, Mohammad Zulfan and Syed Mansoob Murshed. 2007. "Socio-Economic Determinants of Everyday Violence in Indonesia: An Empirical Invetsigation of Javanese Districts, 1994-2003.” Journal of Peace Research 44(6):689-709.

Tadjoeddin, Mohammad Zulfan, Widjajanti I. Suharyo and Satish Mishra. 2001. "Regional Disparity and Vertical Conflict in Indonesia." Journal of the Asia Pacific Economy 6(3):283-304.

Tadjoeddin, Mohammed Zulfan. 2011. "The Economic Origins of Indonesia's Secessionist Conflicts." Civil Wars 13(3):312-332.

Tajima, Yuhki. 2013. “The Institutional Basis of Intercommunal Order: Evidence from Indonesia's Democratic Transition." American Journal of Political Science 57(1):104-119.

Treisman, Daniel. 1999. "Political Decentralization and Economic Reform: A Game-Theoretic Analysis." American Journal of Political Science 43(2):488-517.

Treisman, Daniel. 2007. "What Have We Learned About The Causes Of Corruption From Ten Years Of Cross-National Empirical Research?" Annual Review of Political Science 10:211-44. 
Turner, Mark, Owen Podger, Maria Sumarjono and Wayan K. Tirthayasa. 2003. Decentralization in Indonesia; Redesigning the state. Asia Pacific Press.

van Klinken, Gerry. 2001. "The Maluku Wars: Bringing Society Back In.” Indonesia 71:1-26.

van Klinken, Gerry. 2007. Communal Violence and Democratization in Indonesia. Small town wars. Routledge.

Varshney, Ashutosh, Mohammad Zulfan Tadjoeddin and Rizal Panggabean. 2008. "Creating Datasets in Information-Poor Environments: Patterns of Collective Violence in Indonesia, 19902003." Journal of East Asian Studies 8:361-394.

Wibbels, Erik. 2006. "Madison in Baghdad? Decentralization and Federalism in Comparative Politics." Annual Review of Political Science 9:165-88.

Wibbels, Erik and Kristin Bakke. 2006. "Diversity, Disparity, and Conflict in Federal States." World Politics 59(1):1-50.

Wilson, Chris. 2008. Ethno-Religious Violence in Indonesia. From soil to God. Routledge.

World Bank. 2001. The Imperative for Reform. The World Bank.

Zhukov, Yuri M. 2012. "Roads and the diffusion of insurgent violence: The logistics of conflict in Russia's North Caucasus.” Political Geography 31:144-156. 